\title{
c-MET inhibition: novel treatment for sporadic and MEN1-associated GEP NETs
}

\author{
Maya Elena Lee', Aisha Aderayo Tepede ${ }^{1}$, Adel Mandl'1, Lee Scott Weinstein ${ }^{1}$, Jaydira del Rivero², Sunita K Agarwal' \\ and Jenny E Blau ${ }^{1}$
}

${ }^{1}$ Metabolic Diseases Branch, National Institute of Diabetes and Digestive and Kidney Diseases, National Institutes of Health, Bethesda, Maryland, USA

2Developmental Therapeutics Branch, National Cancer Institute, National Institutes of Health, Bethesda, Maryland, USA

Correspondence should be addressed to J E Blau: Jenny.blau@nih.gov

\begin{abstract}
Gastroenteropancreatic neuroendocrine tumors (GEP NETs) comprise a heterogenous and diverse group of neoplasms arising from a common neuroendocrine cell origin. The majority of these tumors occur sporadically while $\sim 20 \%$ manifest within the context of hereditary syndromes. Germline MEN1 mutations cause a syndrome with an increased susceptibility to multifocal primary GEP NETs. In addition, somatic MEN1 mutations also occur in these sporadic lesions. MEN1 alterations are the most frequent somatic mutation found in pancreatic neuroendocrine tumors. In this review, we explore the implication of the loss of the MEN1-encoded protein menin as a key pathogenic driver in subsets of GEP NETs with downstream consequences including upregulation of the oncogenic receptor c-MET (hepatocyte growth factor receptor). Furthermore, the review will summarize the data related to the clinical presentation, therapeutic standards, and outcomes of these tumors in both sporadic and germline MEN1 mutation-associated contexts. Finally, we present the data on c-MET expression in GEP NETs, clinical trials using c-MET inhibitors and provide an overview of the molecular mechanisms by which c-MET inhibition in these lesions represents a potential precision-medicine targeted approach.
\end{abstract}

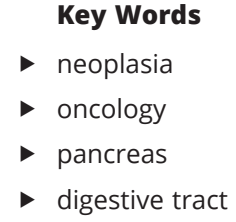

Journal of Molecular Endocrinology (2020) 65, R1-R17

\section{Introduction}

Gastroenteropancreatic neuroendocrine tumors (GEP NETs) represent a heterogeneous group of tumors with an unpredictable clinical course and varying degrees of malignancy. These neoplasms arise from neuroendocrine cells and are characterized by their ability to produce and secrete peptide hormones that can result in syndromes of hormonal excess. While they are rare, the incidence of NETs in the United States has increased 6.4-fold over the past 40 years (Dasari et al. 2017).

NET hereditary syndromes account for $\sim 20 \%$ of all GEP NETs, including multiple endocrine neoplasia (MEN) syndrome types 1 and 4, von Hippel-Lindau (VHL) and neurofibromatosis type 1 (NF1). MEN1 is caused by heterozygous germline-inactivating mutations in the tumor-suppressor MEN1 gene on chromosome 11q13 (Chandrasekharappa et al. 1997, Lemmens et al. 1997, Agarwal 2017). The MEN1 gene encodes a ubiquitously expressed nuclear protein menin, which acts as a tumor suppressor in endocrine cells. Menin operates as a multi-functional protein that interacts with over 40 proteins and is implicated in many biological processes including the regulation of transcription, proliferation, differentiation, and genomic integrity (Agarwal 2017). GEP NETs are frequent in patients with MEN1, occurring in an estimated $80 \%$ of patients by age 80 years (de Laat et al. 2016). Metastatic GEP NETs increase the risk of death 
by $\sim 3.5$-fold in this patient population, and therapeutic options are guided by clinical trials in sporadic GEP NETs (Goudet et al. 2010).

Tumor genomic profiling has elucidated that MEN1 is frequently mutated in sporadic GEP NETs. The evidence is the strongest for sporadic non-functional pancreatic neuroendocrine tumors (NF PNETs) in which MEN1 mutations are found in up to $30-44 \%$ of tumors (Jiao et al. 2011, Scarpa et al. 2017, Raj et al. 2018). Gastric, duodenal and small intestinal NETs may also harbor loss of 11q13 (Yang et al. 2017).

Our group has elucidated a downstream consequence of menin loss which results in an upregulation of c-MET, also known as hepatocyte growth factor receptor (Modali et al. 2015). Targeted therapies based on knowledge of the underlying genetics has proven beneficial in other tumor types, including BRAF inhibitors for melanoma or epidermal growth factor receptor (EGFR) tyrosine kinase inhibitors for EGFR mutations in non-small-cell lung cancer treatment (Lynch et al. 2004, Flaherty et al. 2010). While mutations in MET have led to clinical trials in c-MET tumor-mutated malignancies with varying results, herein we explore an alternative pathway by which c-MET may be an actionable target for GEP NETs, with a particular focus on PNETs.

\section{Clinical overview of MEN1 and sporadic GEP NETs}

\section{Clinical features}

Factors that determine the clinical course and outcome of patients with GEP NETs are multifaceted and include the organ system of origin, hormone secretory properties, the size of the primary tumor, the extent of disease, the tumor grade and the functional status/co-morbidities of the patient. Most sporadic GEP NETs are non-functional and may escape clinical detection until the tumor is large enough to exert a mass effect or to develop distant metastases. On the other hand, functional GEP NETs such as insulinoma, gastrinoma, glucagonoma, vasoactive intestinal peptide secreting tumor (VIPoma), and somatostatinoma, among other rare functional NETs, typically present symptomatically and the tumors are usually small at the time of diagnosis (Table 1). The cell of origin of these neuroendocrine tumors are varied and include $\beta$-cells for insulinomas, G-cells for gastrinomas, $\alpha$-cells for glucagonomas, non- $\beta$ pancreatic islet cells for VIPomas, among others. In patients with MEN1, functional and non-functional primary NETs often occur in the same gland (e.g. multiple primary pancreatic NF and gastrinproducing NET) and within different organs (e.g. duodenum and pancreas). The two most common functional GEP NETs seen in MEN1 are gastrinomas ( 40\%) and insulinomas (10\%) (Thakker et al. 2012).

GEP NETs within the MEN1 patient population are often detected at an earlier age than patients with sporadic NETs. In addition to the inherited predisposition to early NETs, family members of MEN1 patients typically undergo surveillance at a young age (starting at the age of 5 years) and symptoms of functional NETs such as gastrinoma or insulinoma may be identified during routine screenings (Hopper et al. 2019).

\section{Diagnostic evaluation}

A major challenge in the management of NET includes a lack of sensitive biomarkers to diagnose non-functional

Table 1 Functional pancreatic neuroendocrine tumors.

\begin{tabular}{|c|c|c|c|c|}
\hline \multirow[b]{2}{*}{ Tumor type } & \multirow{2}{*}{$\begin{array}{l}\text { Sporadic prevalence } \\
\text { (per million people) }\end{array}$} & \multirow[b]{2}{*}{ Clinical symptoms } & \multicolumn{2}{|c|}{ Mutational landscape } \\
\hline & & & Germline (\%) & Somatic (\%) \\
\hline Insulinoma & $1-4 d$ & $\begin{array}{l}\text { Whipple's triad: symptomatic hypoglycemia } \\
\text { ameliorated by glucose administration with } \\
\text { documented low plasma glucose level <50 mg/dL, } \\
\text { dizziness, irritability, sweating, comaa,b }\end{array}$ & MEN1 (10) ${ }^{\mathrm{h}}$ & $\begin{array}{l}Y Y 1(0-30)^{f} \\
\text { MEN1 }(0-17) \mathrm{g}\end{array}$ \\
\hline Gastrinoma & $0.1-15^{e}$ & $\begin{array}{l}\text { Gastroesophageal reflux disease, duodenal ulcers } \\
\text { with bleeding and/or perforations, diarrhea, } \\
\text { weight loss, amelioration with proton pump } \\
\text { administration }\end{array}$ & $\operatorname{MEN1}(40)^{\mathrm{h}}$ & MEN1 (33)g \\
\hline VIPoma & $0.1^{\mathrm{a}}$ & Severe diarrhea, weight loss, hypokalemiac & MEN1 $(<2)^{i}$ & Unknown \\
\hline Glucagonoma & $0.001-0.01^{a}$ & $\begin{array}{l}\text { Diabetes mellitus, necrolytic migratory erythema, } \\
\text { diarrhea, stomatitisa,b }\end{array}$ & MEN1 $(<2) i$ & Unknown \\
\hline Somatostatinoma & $0.025^{a}$ & $\begin{array}{l}\text { Gallstones, weight loss, diarrhea, steatorrhea, } \\
\text { diabetes mellitusa,b }\end{array}$ & MEN1 $(<2)^{i}$ & Unknown \\
\hline $\mathrm{ACTH}$ & less than 10 case reportsj & Cushing's syndrome, liver metastesesj & Unknown & Unknown \\
\hline
\end{tabular}

References: a (Jensen et al. 2012); b(Lewis et al. 2017); c(Farina et al. 2019); d(Okabayashi et al. 2013); e(Zhang et al. 2016); ${ }^{\mathrm{f}}($ Parekh et al. 2018); g(Zhuang et al. 1997); ' (Agarwal 2017); i (Vargatu 2016); j(Byun et al. 2017). 
GEP NETs. The 'NETest', a blood-based, multi-gene expression assay has been developed for use in sporadic NETs and has reported a higher degree of sensitivity and specificity (>95\%), especially when compared to poor markers such as chromogranin A (Modlin et al. 2013). However, the utility of this test has not been evaluated in patients who may present with tumors in multiple endocrine and non-endocrine tissues, as is the case in MEN1. Similar to other liquid biopsy tests, this test is currently not routinely used in clinical practice due to cost and availability.

Without reliable and sensitive biochemical markers for non-functional NETs, various imaging modalities are available, including, but not limited to, endoscopic ultrasound (EUS), computerized tomography (CT), MRI, and ${ }^{68} \mathrm{Ga}$-DOTATATE PET/CT. Sporadic NET patients typically undergo anatomic imagining (CT/MRI/EUS) in addition to ${ }^{68} \mathrm{Ga}$-DOTATATE PET/CT given that most patients have one primary tumor and all other lesions are metastatic from the single original lesion. However, due to the frequent tumor multiplicity in MEN1, there is no universal consensus about which imaging techniques are best and/or most sensitive at detecting GEP NETs in MEN1. Expert guidelines from 2012 recommend surveillance imaging for GEP NETs with MRI, CT, or EUS every 1-2 years depending on manifestations. Newer agents, including ${ }^{68} \mathrm{Ga}$-DOTATATE PET/CT are becoming more commonly used (and replacing ${ }^{111}$ In-labeled octreotide scintigraphy), but expert opinion and data are lacking on the usefulness of this imaging modality for routine yearly screening. ${ }^{68} \mathrm{Ga}$-DOTATATE has a 100 -fold higher affinity for somatostatin receptor 2 (SSTR2), and about an equal affinity for somatostatin receptor 5 (SSTR5) compared to ${ }^{111}$ In-pentetreotide scintigraphy which likely accounts for its superiority of localization and higher spatial resolution (Reubi et al. 2000). Other agents, such as 18F-FDOPA PET/CT and ${ }^{68} \mathrm{Ga}$-DOTA-exendin-4 PET/CT have also been used to localize rare functional sporadic and MEN1 tumors such as pheochromocytoma and insulinoma (Luo et al. 2016, Tepede et al. 2019). These newer agents offer the possibility to identify a tumor based on receptor concentration for functional neuroendocrine tumors. Ideally, one would want to localize a functional tumor within a gland that has multiple NETs (or possibly identify a pheochromocytoma in a patient with bilateral, heterogenous adrenal nodules, for example).

Each imaging method has risks and benefits that must be considered when creating a comprehensive care plan for an MEN1 patient. For example, CT scans are widely available and affordable, with a sensitivity for detecting MEN1-associated and sporadic GEP NETs of 70-94\% (Challis et al. 2019). However, the repeated use of this modality exposes patients to increased cumulative radiation, which has been evaluated in other inherited endocrine syndromes such as von Hippel landau (VHL) (Tirosh et al. 2019). MRI has an 88\% sensitivity for visualizing GEP NETs in MEN1 patients and limits radiation exposure, but may be associated with the accumulation of gadolinium deposits within the nuclei of the brain. EUS has a reported NET detection rate of $90 \%$, a sensitivity of $93 \%$, and specificity of $95 \%$, but it can miss areas of the pancreatic tail, is not as widely available, and is a more invasive test compared to the aforementioned imaging methods (Challis et al. 2019). A recent systematic review evaluating the diagnostic accuracy of different imaging modalities for MEN1-associated non-functional PNETs found that MRI is preferred over CT due to higher sensitivity and less radiation exposure (van Treijen et al. 2018). Future studies and consensus are needed to inform providers regarding the best surveillance and follow-up modality for GEP NETs in MEN1.

\section{Pathologic classification and prognosis}

All NETs are classified by the 2017 World Health Organization (WHO) Tumor Grading System (Rindi et al. 2018). NETs are categorized into grades 1 (G1), 2 (G2) and 3 (G3) based on the Ki-67 proliferation and/or mitotic indices. Ki-67 grades are classified as G1: $<3 \%$, G2: 3-20\%, and G3: $>20 \%$, and mitotic index as G1: $<2 / 10$ high powered field (HPF), G2: 2-20/10 HPF, and G3: >20/10 HPF. Generally, well-differentiated NETs (G1) are indolent tumors and expresses typical markers of neuroendocrine differentiation. Poorly differentiated high-grade tumors (G3) are now classified as neuroendocrine carcinoma (NEC), which can be further characterized as small-cell or large-cell type and behave more aggressively than the typical indolent, well-differentiated NET (Choe et al. 2019). Finally, undifferentiated NETs are classified as G4 (Dasari et al. 2017).

For sporadic and MEN1-associated tumors, this updated grading system helps to predict overall patient prognosis. Poorly differentiated NECs are associated with increased risk of metastases and worse survival as compared to well-differentiated NETs (Conemans et al. 2017a). A review of the Surveillance, Epidemiology, and End Results (SEER) database of 50,000 US NET patients over 50 years by Dasari et al. confirms that G1 NETs have the highest median overall survival of 16.2 years, followed by G2 NETs at 8.3 years, and G3 and G4 (now called NEC) 
NETs at 10 months (Dasari et al. 2017). Specifically for MEN1 patients, GEP NETs are most commonly G1 and G2, with only a few case reports demonstrating G3 NECs (Waldmann et al. 2008, Beijers et al. 2019). A large cohort study ( $n=220$ MEN1 patients) demonstrated that $56 \%$ of patients had a GEP NET of which 15\% developed liver metastases by an average age of 51 years old (range 31-74 years old) (Conemans et al. 2017b). Of the MEN1 patients with liver metastases, 50\% had died after a median follow-up of 4 years, yielding an overall survival rate at 10 years of 50\%. In MEN1, gastrinomas and non-functional PNETS are responsible for the most cancer-related deaths due to their metastatic potential (van Treijen et al. 2018, Vinault et al. 2018).

\section{Management of sporadic and MEN1 GEP NETs}

\section{Surgical intervention}

Surgical resection is the only possible curative intervention for both functional and non-functional GEP NETs (Ramage et al. 2005, Frost et al. 2018). For sporadic tumors, as many as $40 \%$ of NETs are metastatic at the time of diagnosis, limiting surgical intervention if the tumor is already widespread (Cives \& Strosberg 2015). Another surgical challenge includes the inability to localize the culprit lesion (e.g. occult insulinoma), which requires an experienced NET center to localize the tumor and an experienced endocrine surgeon (Hirshberg et al. 2002). For functional NETs, the goal of surgical resection is to relieve symptoms associated with hormone hypersecretion and prevent metastasis.

On the other hand, treatment of non-functional PNETs in MEN1 patients often follows a conservative approach. Surgical resection is only recommended once the primary tumor is at or above $2 \mathrm{~cm}$ (Thakker et al. 2012). Additionally, the tendency of GEP NETs to be multifocal and recurrent in MEN1 patients must be considered when planning surgical interventions in order to optimize patient outcomes while minimizing surgical invasiveness (Demeure et al. 1991). Following surgery, continued screening and follow-up are important in MEN1 patients to assess their continued risk for new NETs in remnant gastroenteropancreatic tissue (Dralle et al. 2004). Such guidelines are internationally recognized and based on data which found a correlation between increased pancreatic tumor size $(>2 \mathrm{~cm})$ and increased risk of developing metastatic disease and/or death (Triponez et al. 2006). Surgical options depend on tumor location, size and extent of metastasis and may include distal or total pancreatectomy, Whipple procedure, and/or tumor enucleation.

\section{Medical management options}

Well-differentiated NET treatment options include somatostatin analogues (SSAs), receptor tyrosine kinase inhibitors (TKIs), mechanistic target of rapamyacin (mTOR) inhibitors, peptide receptor radionuclide therapy (PRRT), among other chemotherapies.

\section{Somatostatin analogues}

SSAs are typically the first line of treatment and were FDA approved in 1998. These agents target various isoforms of somatostatin receptors (SSTRs), which are a class of G-protein-coupled receptors present on the surface of GEP NETs. Well-differentiated tumors are known to express SSTRs at a higher density compared to poorly differentiated tumors. Within the gastrointestinal tract, low-grade NETs typically express a high density of SSTR2 (Reubi 2004). Lanreotide or octreotide long-acting release (LAR) acetate injections are two SSAs which have a high binding affinity for SSTR2 and have been utilized for their antisecretory and tumor stabilization effects. The PROMID study demonstrated that mid-gut NET treatment with $30 \mathrm{mg}$ of octreotide LAR every 4 weeks significantly delayed time to tumor progression (TTP) (14.3 months vs 6 months, treatment vs placebo, respectively) (Rinke et al. 2019). Additionally, the treatment group had a significant delay in the worsening of symptoms such as fatigue, pain, insomnia, and diarrhea. In the Controlled Study of Lanreotide Antiproliferative Response in Neuroendocrine Tumors (CLARINET) study, patients with intestinal/pancreatic NETs were treated with 120 mg of lanreotide vs placebo every four weeks for almost 2 years, and progression-free survival (PFS) was found to be significantly increased with lanreotide treatment compared to placebo (65.1 vs 33\% in treatment vs placebo at 1 year) (Caplin et al. 2014, Dromain et al. 2019). When tumor growth was analyzed against baseline CT and MRI imaging, the treatment group was observed to have a median tumor growth rate of $2.1 \%$ per month compared to $2.7 \%$ in the the placebo group, which was significantly decreased $(P=0.008)$ after 12 weeks of lanreotide treatment compared to placebo (Caplin et al. 2014). One challenge in the design of these studies includes the low rates of objective radiologic response of NETs, as noted above in the $0.6 \%$ difference, which is also subjected to subjective variability. However, given the typical slow 
growth of low-grade NETs, tumor stabilization may be an alternative endpoint and should be considered in the design of clinical trials in NETs. Increased response rates of tumor stabilization, reported between 40-60\% in NET patients with less disease progression at onset of treatment, supports this alternative trial endpoint (Cives \& Strosberg 2015).

\section{Receptor tyrosine kinase inhibitors (TKIs)}

Tumor progression despite the administration of SSA requires escalation of medical treatment. Options include receptor TKIs, for which sunitinib has been FDA approved for metastatic NETs since 2006. TKIs target vascular endothelial growth factor (VEGF) and platelet-derived growth factor (PDGF) receptors, which are crucial for tumor growth and survival. Specifically, sunitinib targets PDGF- $\alpha$ and PDGF- $\beta$ receptors, as well as VEGF1 and VEGF2 receptors (Deeks \& Raymond 2011). An early signal for efficacy in NET resulted from a phase I study of sunitinib in which $1 / 6$ th of tumors had a response to sunitinib (in highly vascularized gastrointestinal NETs) (Kulke et al. 2008). A non-randomized trial in advanced NET showed a $16.7 \%$ partial response rate (11/66 PNETs) and stable disease in $62 \%$ (limited by median treatment of 7.2 months). However, the quality of life was not significantly improved and the side effect profile was intolerable for some patients (Wiedmann \& Mossner 2012). Ultimately, a phase III study of sunitinib for patients with advanced, well-differentiated PNETs was stopped early for efficacy, demonstrating a median PFS of 11.4 months as compared with 5.5 months with placebo. However, the side effect profile remained significant, and $\sim 30 \%$ of patients reported diarrhea, nausea, asthenia, vomiting, while palmar-plantar erythodysethesia and hypertension were present in 23 and 26\% of patients, respectively (Deeks \& Raymond 2011).

\section{Mammalian target of rapamyacin (mTOR) inhibitors}

Everolimus is an oral inhibitor of mTOR that was FDA approved in 2016. The mTOR pathway regulates proliferation, cell growth, and angiogenesis of tumor cells (Faivre et al. 2006). Data for the use of everolimus mainly stem from the four RADIANT trials. The first RADIANT-1 study was a phase II trial evaluating metastatic PNETs which found that treatment with or without concomitant octreotide LAR was promising (Yao et al. 2008). Further evidence from RADIANT-2 evaluating octreotide plus everolimus or placebo did not meet the pre-specified overall survival endpoint in PNET patients (Pavel et al. 2011).
A number of design factors may have influenced these results, including a lower performance status, a higher incidence of lung NET and more frequent prior use of chemotherapy in the treatment arm. Nevertheless, the survival of the treatment subjects ( 6.3 months) was not significantly different than that of the placebo group. Notably, serious adverse events led to discontinuation of the study in $21.1 \%$ of subjects in the treatment arm (compared to $5.9 \%$ of subjects in the placebo arm). RADIANT-3, the largest study at the time to be conducted in NETs, enrolled 410 patients with advanced, low-grade or intermediate-grade PNETs (Yao et al. 2011). Progressionfree survival was improved in the treatment group, 11.0 months with everolimus vs 4.6 months with placebo, with a $65 \%$ reduced risk of progression or death (HR 0.35; 95\% CI 0.27-0.45; $P<0.001)$. The final RADIANT-4 study was a phase III study on patients with G1, G2 advanced GEP NETs $(n=175)$ or lung NETs $(n=90)$ (Yao et al. 2016). There was a $44 \%$ benefit in PFS in GEP NET patients, and tumor shrinkage was observed in 64 vs $26 \%$ of patients (treatment vs placebo, respectively).

\section{Peptide receptor radionuclide therapy (PRRT) and others}

While the aforementioned therapies represent beneficial medical treatments for rare disease, options that offer patients improved survival or a significant delay in tumor progression over extended periods of time are limited. A promising new approach is the use of PRRT in NETs. To induce cellular damage, a radionuclide ${ }^{90} \mathrm{Y}$ or ${ }^{177} \mathrm{Lu}$ ) is linked to a peptide (SSTR agonist, e.g. TOC-Tyr3 octreotide or TATE-Tyr3 octreotate) by means of a chelator (e.g. DOTA). The $\beta$-emitting radionucleotide that results from the binding of the agents to the SSTRs on the tumor cell membrane results in ligand internalization which ultimately leads to cell death. Currently in the United States only ${ }^{177} \mathrm{Lu}$-DOTATATE is FDA approved, although this agent has been used in Europe for over a decade (Frost et al. 2018). The NETTER 1 trial supported the FDA decision for approval (Strosberg et al. 2017). This study included 229 patients with well-differentiated, progressive, locally advanced, inoperable or metastatic SSTR-positive (determined by ${ }^{68}$ DOTATATE PET/CT positive uptake in the tumor) midgut NET and found that the estimated rate of PFS was $65.2 \%$ in the treatment group compared to $10.8 \%$ in the control group at 20 weeks. Furthermore, response rate was significantly $(P<0.001)$ greater in the treatment group (18\%) than the control group (3\%).

Somatostatin antagonist treatment is another modality being investigated. As opposed to SSTR agonists which 
bind to elicit a cellular response, antagonists block agonist binding and thus the agonist response. In 4 patients with progressive NETs, ${ }^{177}$ Lu-DOTA-JR11 treatment resulted in partial remission in 2 patients, stable disease in 1 patient and a mixed response in the final patient (Wild et al. 2014). Somatostatin antagonists (e.g. ${ }^{177} \mathrm{Lu}$-DOTA-JR11 or $\left.{ }^{177} \mathrm{Lu}-\mathrm{OPS} 201\right)$ are also being investigated for theranostic use (Fani et al. 2017). Although the full side effect profile remains unknown, continued investigations, including the results of a preliminary study of the efficacy of ${ }^{177} \mathrm{Lu}-\mathrm{OPS} 201$ are forthcoming (NCT02592707).

Other therapies beyond the scope of this review include combination treatment of capecitabine and temozolomide, interferon- $\alpha$, and interventional radiofrequency (IR) ablation. Current ongoing studies of combination treatments and newer agents (NCT03049189, NCT02955069, NCT03375320) will help us better understand the relative benefits and disadvantages. However, there is still a need for randomized head-tohead clinical trials.

In addition, it is important to recognize that many trials do not include or do not report the number of patients with germline MEN1 mutation-positive MEN1 syndrome. Thus, we have an insufficient understanding of how these therapies affect this subset of patients. Mechanistic insights to guide therapeutic targets in MEN1-associated tumors is a critical step to improve outcomes for patients with MEN1 and possibly patients with MEN1-mutated GEP NETs.

\section{The role of c-MET in malignancy}

\section{Impact of c-MET alterations}

c-MET is a tyrosine kinase receptor for hepatocyte growth factor (HGF). HGF ligand binding causes dimerization of the c-MET receptor and subsequent autophosphorylation of the intracellular domains, resulting in activation of downstream signaling pathways. These signals, including phosphoinosintide 3-kinase (PI3K), GRB-associatedbinding protein 1 (GAB1), and RAS, have been shown to be key regulators in cellular growth, survival, and motility (Puccini et al. 2019) (Fig. 1).

MET activating mutations were discovered by genomewide analysis of families with hereditary papillary renal carcinoma (HPRC), and its role as a somatically mutated driver gene has been expanded to include papillary renal carcinomas, as well as brain, breast, colorectal, endometrial, esophageal, gastric, head and neck, hepatic, kidney, lymphomas, medulloblastoma, melanoma, non-small-cell-lung, ovarian, and pancreatic cancers (Schmidt et al. 1997, Peters \& Adjei 2012). Activating MET mutations are found in exons 18 and 19 , as well as in the semaphorin domain (e.g. missense mutation E168D) and juxtamembrane domain (e.g missense mutation T1010I, P1009S, and exon 14 skipping) of the receptor. Furthermore, c-MET overexpression is associated with poorer prognosis and increased peritoneal and liver metastasis in gastric cancer patients (Toiyama et al. 2012, Bradley et al. 2017).

MET mutations have not been observed in sporadic PNETs or other NETs such as lung and small intestine in whole genome or exome sequencing analyses (Jiao et al. 2011, Francis et al. 2013, Scarpa et al. 2017, Simbolo et al. 2017, 2019, Raj et al. 2018). Although receptor mutations have not been observed in NETs, c-MET has been found to be overexpressed in PNETs through regulation at the promoter level (as explained below) or other unknown mechanisms (Hansel et al. 2004, Modali et al. 2015, Krampitz et al. 2016, Chan et al. 2018). An in-depth profile of primary and metastatic PNETs implicated c-MET to be essential for tumor growth in NET xenograft models (Krampitz et al. 2016). Synthetic stimulation of the c-MET receptor in xenograft models with a monoclonal anti-c-MET antibody 3D6 (c-MET agonist) was shown to significantly increase the growth of transplanted NET tumor xenografts. None of the PNET samples lacking c-MET successfully became xenografts, supporting the role of c-MET activation and signaling in tumor cell proliferation and survival. Using a tissue microarray of well-differentiated PNETs $(n=74)$, high c-MET expression correlated with decreased survival (Krampitz et al. 2016), similar to the data in gastric cancer patients above. Immunofluorescence analysis confirmed the co-staining of chromogranin A (a marker of NETs) and c-MET in a patient's liver and lymph node metastases, suggesting a c-MET inhibitor could additionally target metastasis. Based on these data, targeting c-MET for therapy has been intensively investigated for potential bench-to-bedside applications.

\section{Current applications of c-MET inhibition in cancer therapy}

Inhibition of c-MET signaling in cancer treatment is achieved via one of two mechanisms: monoclonal antibodies (MAB) that prevent HGF/c-MET interaction and/or c-MET dimerization or small-molecule kinase inhibitors which block the phosphorylation of c-MET after ligand binding. The small-molecule kinase inhibitor 


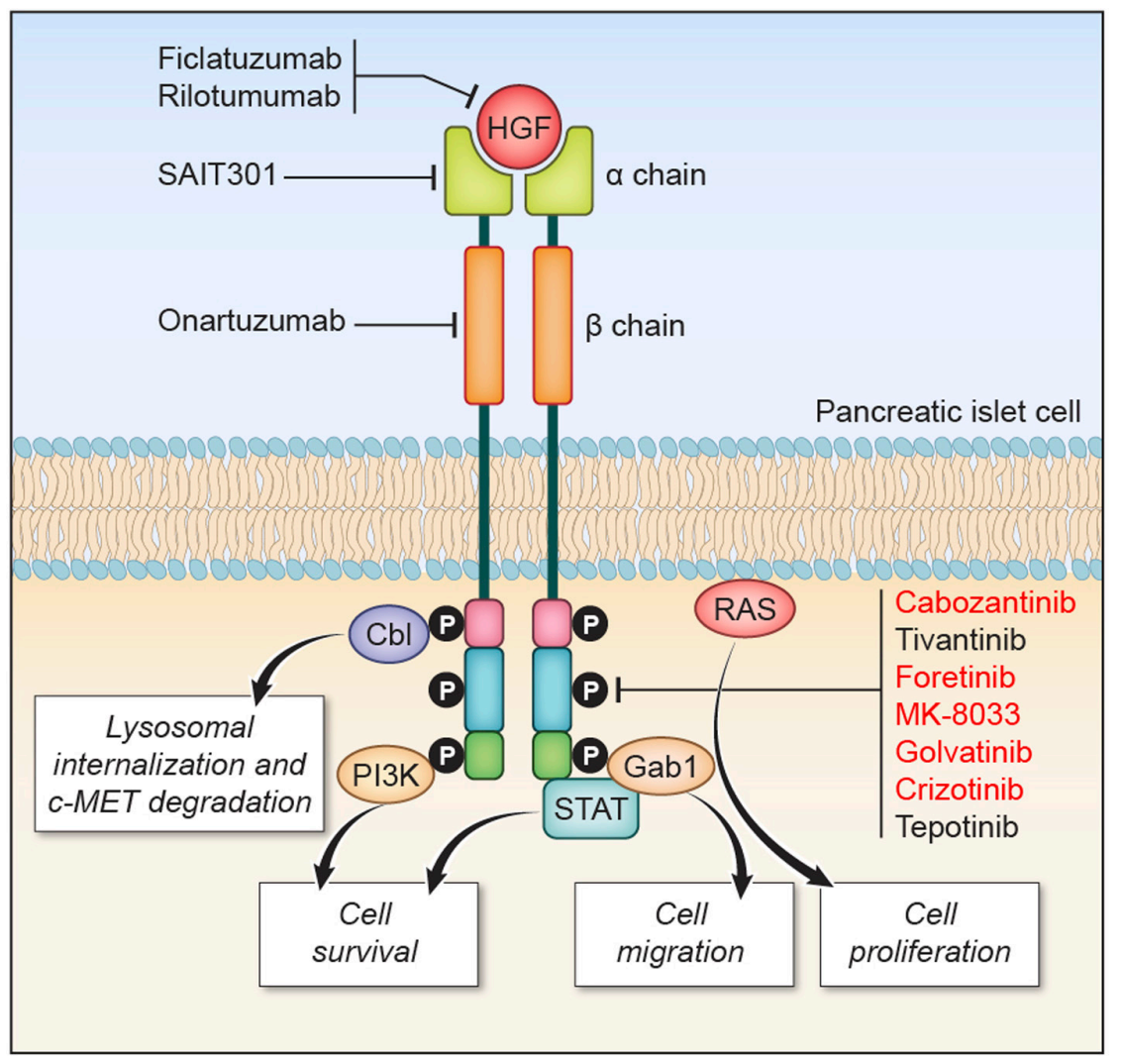

\section{Figure 1}

HGF/c-MET interaction and associated inhibitors. Binding of the HGF ligand to the $\alpha$-chain induces dimerization and subsequent autophosphorylation of the c-MET receptor. Monoclonal anti-HGF antibodies, such as ficlatuzumab and rilotumumab, and anti-c-MET receptor antibodies like SAIT301 and onartuzumab, inhibit downstream signaling by blocking ligand/receptor interactions. Upon ligand binding, phosphorylation events prompt the recruitment of several intracellular proteins. $\mathrm{Cbl}$ functions as a ubiquitinating effector to promote lysosomal recognition and subsequent degradation of c-MET. PI3K phosphorylates downstream agent protein kinase B (AKT), which activates mTOR pathways to promote cell survival. Signal transducer and activator of transcription (STAT) signaling also contributes to this pathway. GAB1 interacts with several downstream proteins, including STAT, to signal cell migration. Residing within the intracellular membrane, RAS induces a signaling cascade which promotes cell proliferation. Inhibitors that target phosphorylated intracellular domains of c-MET, such as cabozantinib, tivantinib, foretinib, MK-8033, glovantinib, crizotinib, and tepotinib, aim to block the downstream effects of HGF binding. The red highlighted inhibitors are not selective for c-MET. Cabozantinib, foretinib, MK-8033, golvantinib, crizotinib, and tepotinib all bind competitively with ATP (Classes I and II) while tivantinib does not (Class III). interventions can be further subcategorized into Classes I, II and III. Classes I and II inhibitors are ATP-competitive and specifically bind to different locations of the ATP-binding domain on the c-MET receptor surface. Class III inhibitors are non-ATP-competitive small molecule inhibitors, that work via preventing the autophosphorylation of the intracellular domains of the receptor (Mughal et al. 2013) (Fig. 1).

c-MET inhibitors have proceeded through pre-clinical and clinical trials in different forms of solid tumors, including gastrointestinal cancers (Table 2). For example, tepotinib, an ATP competitive c-MET inhibitor, has been shown to suppress tumor growth and reduce the number of lung metastases from hepatic tumors and is currently in phase Ib clinical trials (Bladt et al. 2014). In another trial investigating the safety and efficacy of tepotinib treatment in patients with solid tumors, two patients with lung neuroendocrine carcinoma were treated in Regimen 1 (30-400 mg tepotinib once daily for 14 days), but no further data on efficacy of that subgroup is available (Falchook et al. 2019).

Tivantinib, a Class III c-MET inhibitor, was shown to successfully reduce c-MET signaling, induce apoptosis, and decrease angiogenesis of hepatocellular carcinoma
(Porta et al. 2015). However, during phase II clinical trials, toxic side effects were noted such as the development of neutropenia and anemia in some patients, and higher doses of tivantinib correlated to increased risk of adverse events. Other inhibitors such as SU11274, a Class I inhibitor, have only been tested in in vitro models. Rilotumumab, a MAB c-MET inhibitor which targets HGF, was found not to be an effective treatment for patients with advanced MET-mutation positive gastric or gastroesophageal junction cancers (Catenacci et al. 2017).

In one of the only clinical trials relating PNETs with c-MET inhibition, cabozantinib (a c-MET and VEGFR2 inhibitor) treatment in patients with advanced carcinoids and PNETs showed partial responses in both tumor types (15\% PNET, $14.6 \%$ carcinoids), and demonstrated that $75 \%$ of patients with PNETS achieved stable disease response, which was the primary endpoint (Chan et al. 2017). Median PFS achieved in the carcinoid cohort was 31.4 months, and 21.8 months in the PNETs cohort (placebo data pending full publication of results). The toxicity profile was consistent with previous observations in other trials (Chan et al. 2017). The efficacy of c-MET inhibitors as a potential treatment for GEP NETs and PNETs is still undefined, but shows promise. 

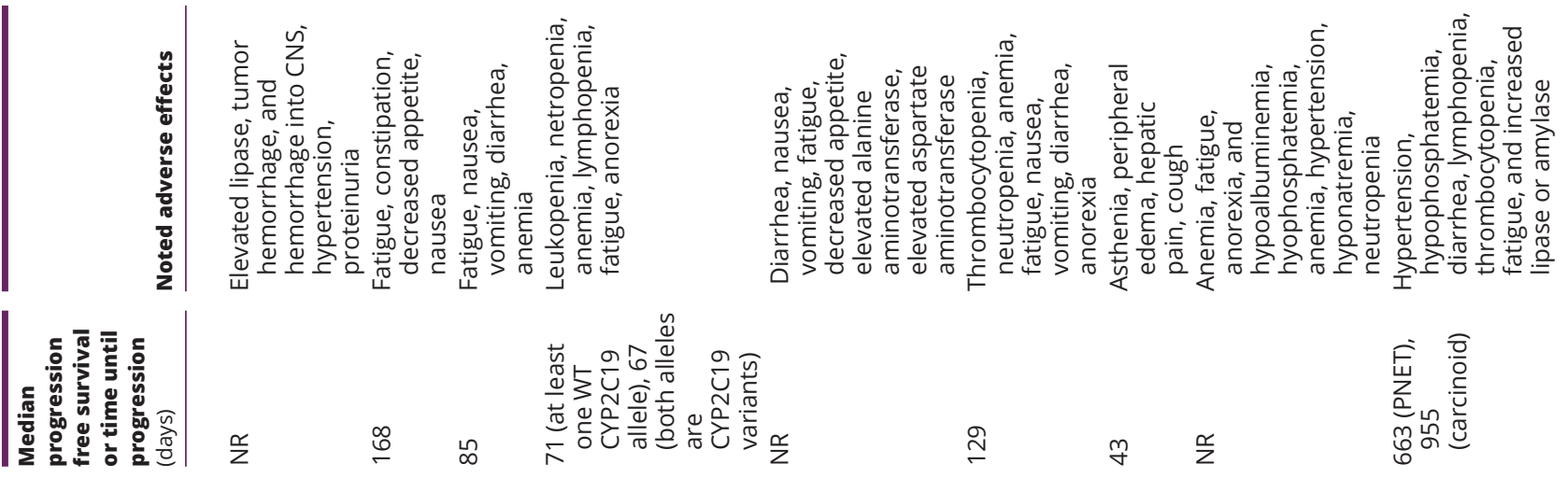

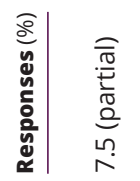

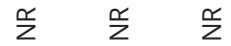

$\stackrel{\alpha}{2}$

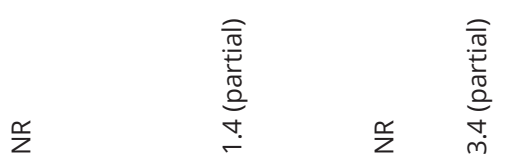

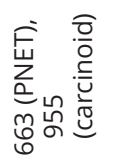

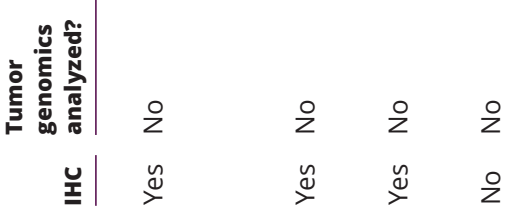

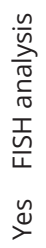

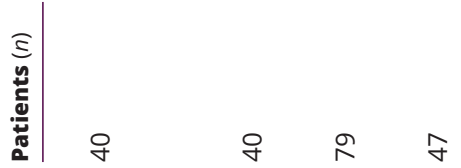

$\stackrel{\oiiint}{\searrow}$

$\begin{array}{lll}\stackrel{0}{z} & \stackrel{0}{z} & \circ \\ \stackrel{0}{y} & \stackrel{y}{\nu} & \circ\end{array}$

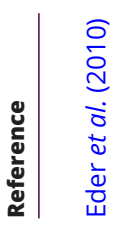

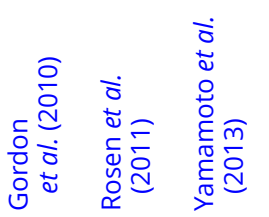

m
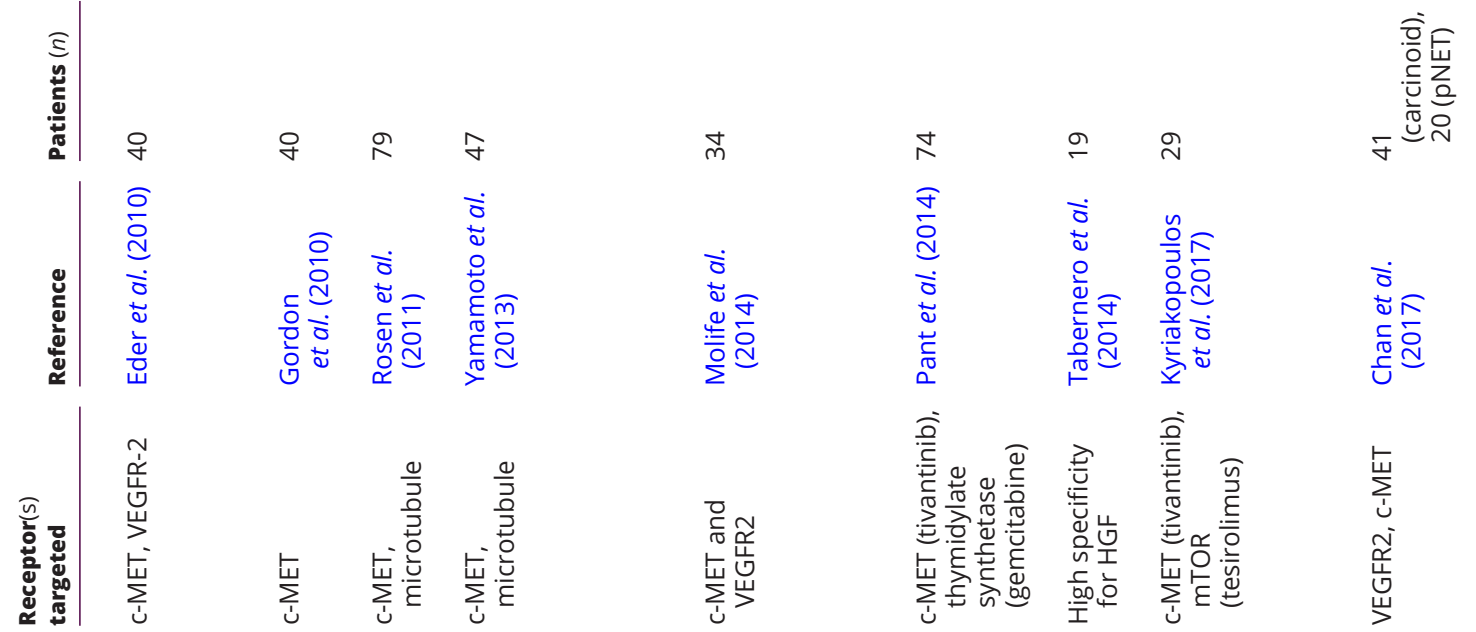

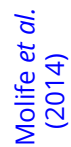

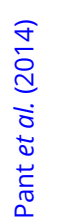

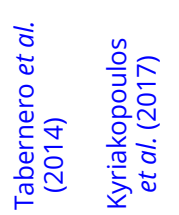

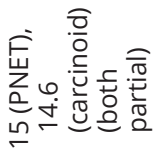

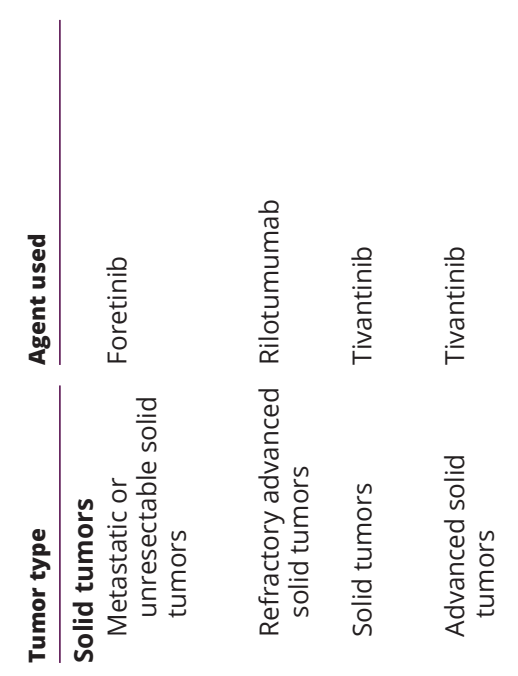

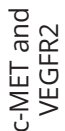
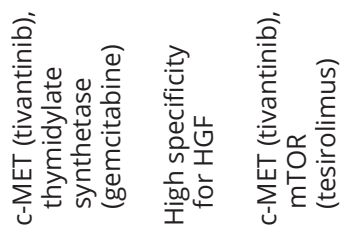

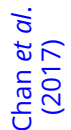
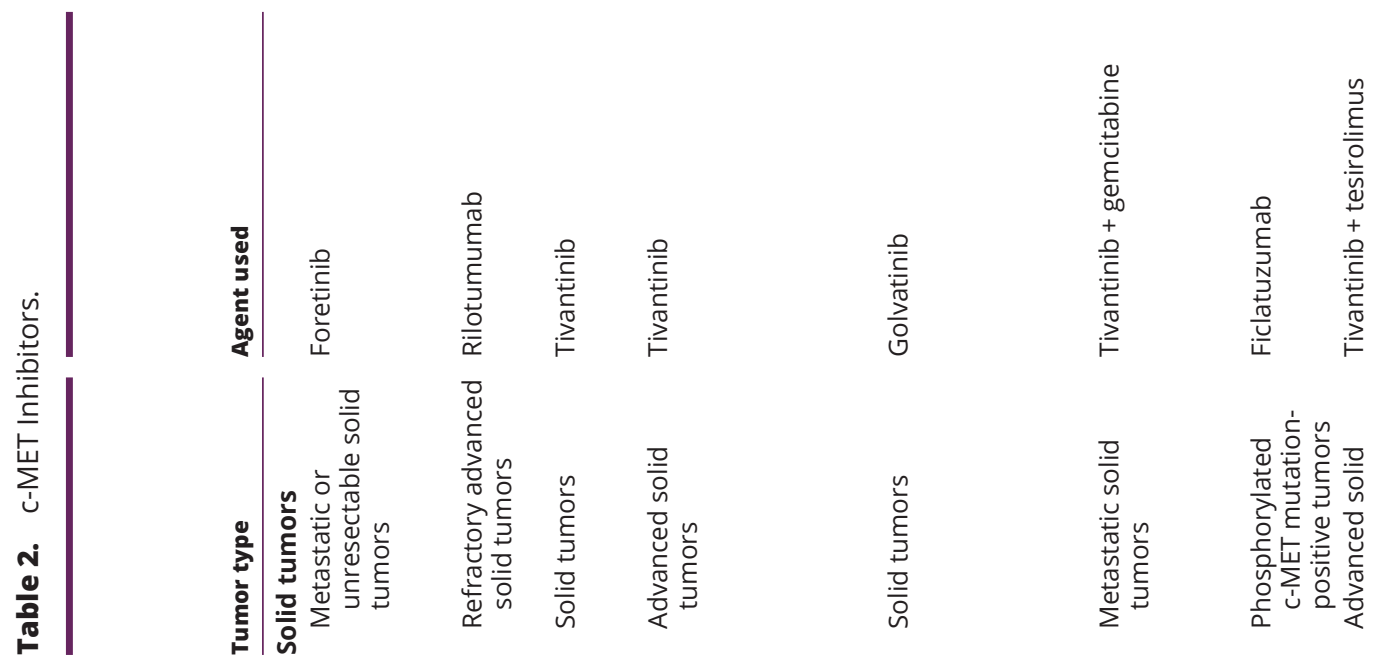

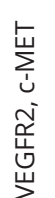

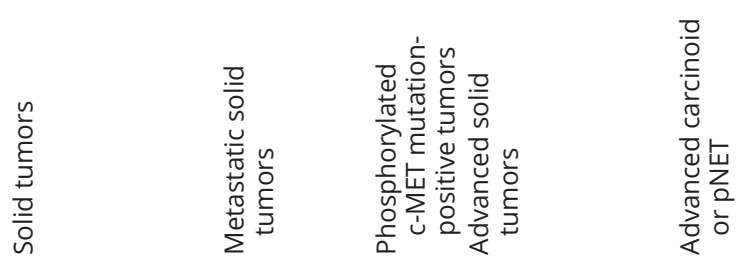

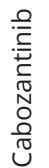


뚱
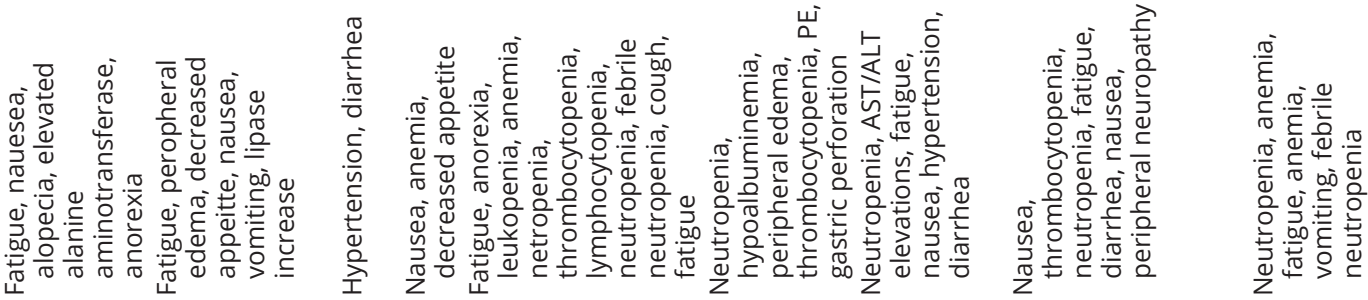

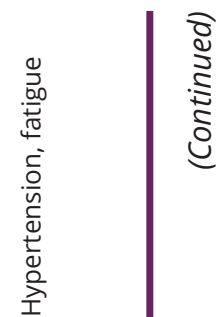

in

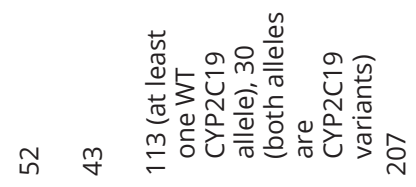

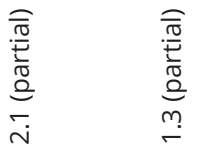

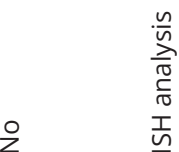

$\stackrel{y}{\rightleftharpoons} \quad \stackrel{y}{\varnothing}$

爱 爱 $\frac{\mathscr{c}}{z}$

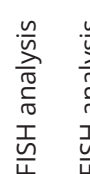

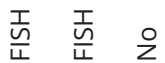

$\stackrel{\varrho}{\rightleftharpoons} \stackrel{\check{\Perp}}{\succ}$

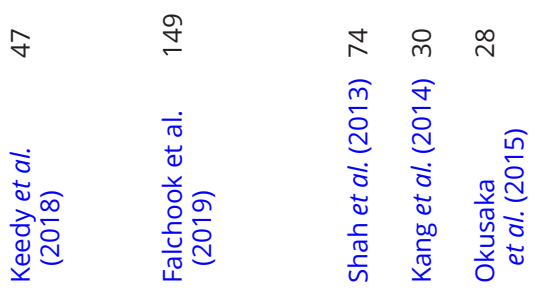

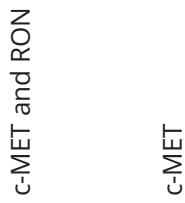

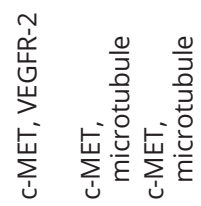

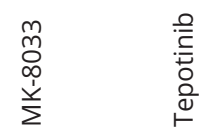

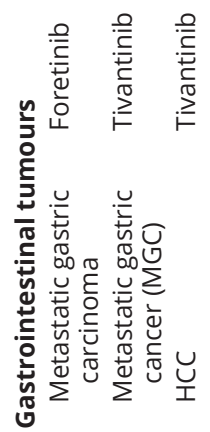

https://jme.bioscientifica.com

(C) 2020 Society for Endocrinology Published by Bioscientifica Ltd. Printed in Great Britain

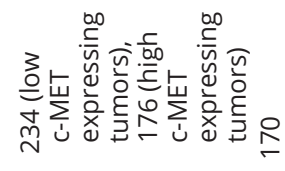

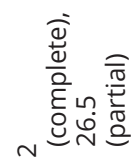

$\begin{array}{lll}\stackrel{\circ}{z} & \stackrel{2}{z} & \stackrel{2}{z} \\ \stackrel{y}{y} & \stackrel{0}{z} & \stackrel{y}{z}\end{array}$

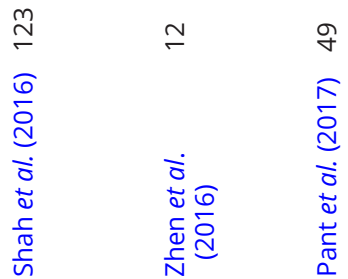

ำ ก

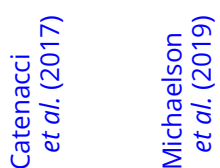

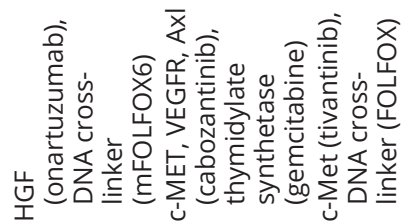

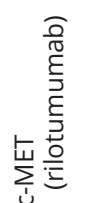

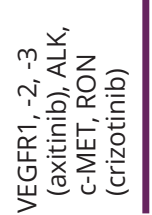

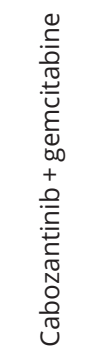
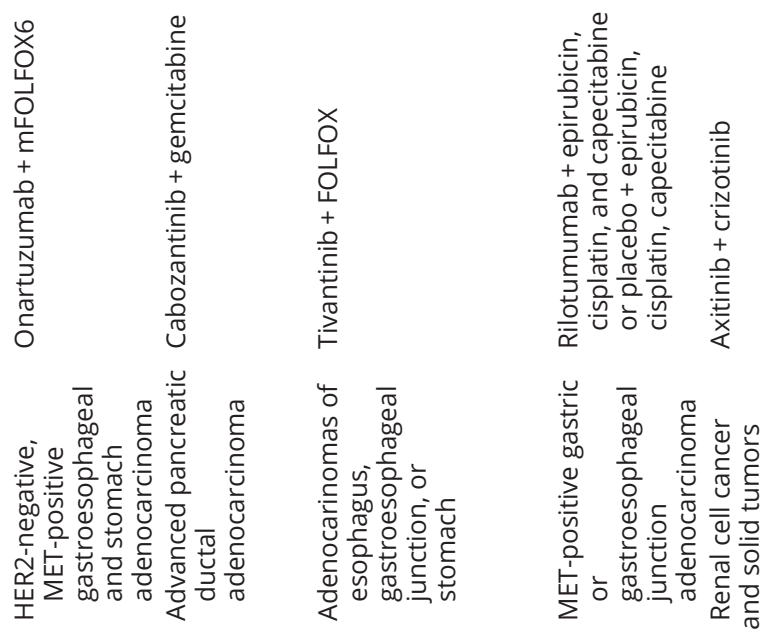


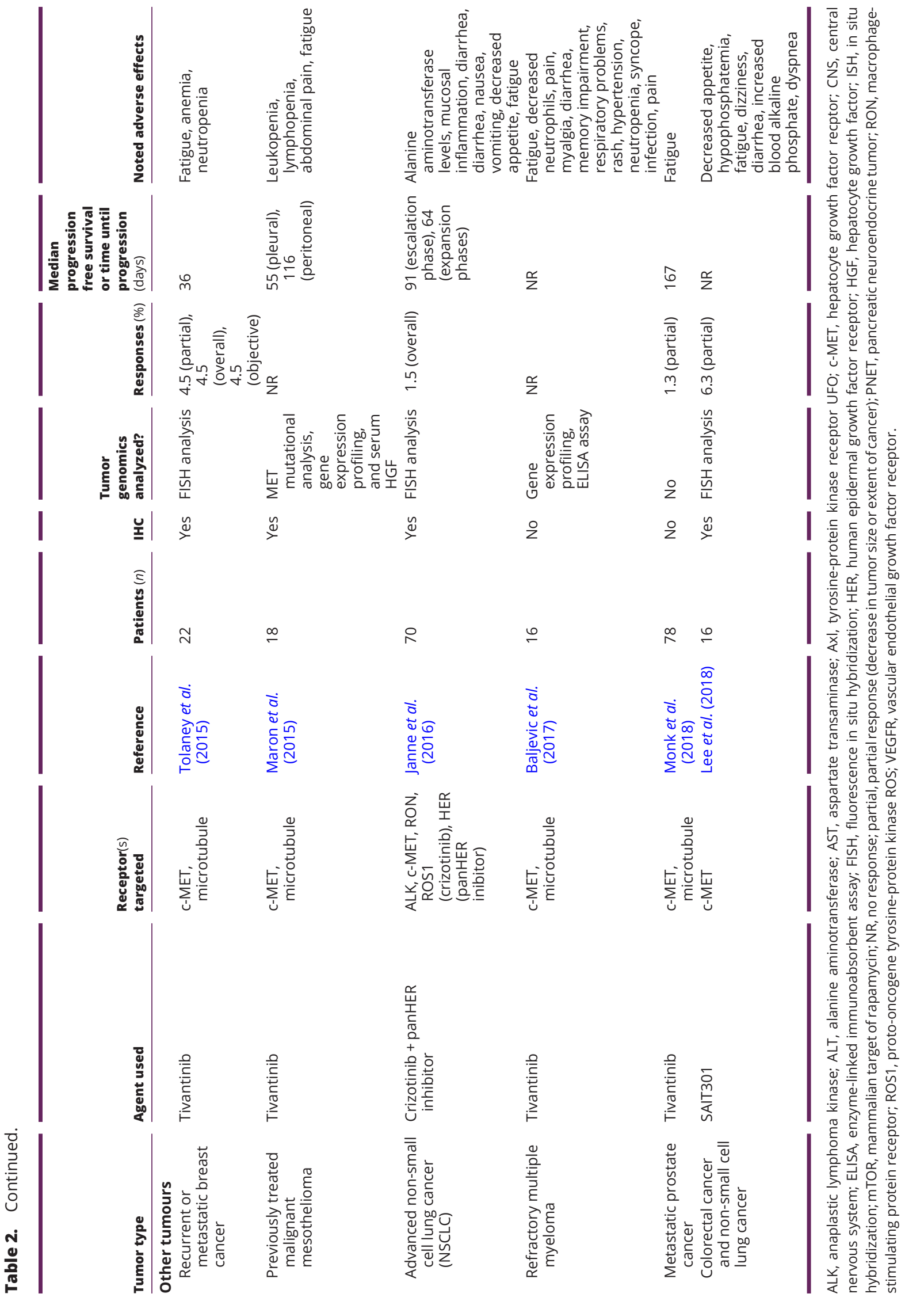




\section{c-MET inhibition as a potential target in MEN1 mutated GEP NET tumors}

\section{In vitro and in vivo data}

A major obstacle in studying c-MET and the effects of c-MET inhibition in PNETs is the lack of suitable PNET pre-clinical models, particularly mouse models, with features of the more common non-functional tumors. The only human PNET cell line APL1, derived from a primary PNET, is very slow growing and not yet used extensively for in vitro experiments (Krampitz et al. 2016). The three other PNET cell lines QGP-1, BON1, and NT-3 do not truly represent PNETs. QGP-1 has a mutation in the KRAS oncogene which is not found in PNETs (Kaku et al. 1980, Vandamme et al. 2015). BON1 is not derived from a primary tumor, but is derived from a lymph node metastasis (Evers et al. 1991). Lastly, NT-3 is derived from the lymph node metastases of PNETs (Benten et al. 2018). There are various in vivo mouse models that develop insulin-secreting tumors, including (1) the germline Men1+/- knockout in which over $80 \%$ develop insulin-secreting PNETs by 60 weeks (Crabtree et al. 2001, Bertolino et al. 2003a, Loffler et al. 2007, Harding et al. 2009), (2) $\beta$-cell specific Men1 knockout where $100 \%$ of mice develop insulinoma by 40 weeks (Bertolino et al. 2003b, Crabtree et al. 2003, Biondi et al. 2004) and (3) RIP-Tag2 mice which develop invasive insulinoma (Hanahan 1985). The generation of reproducible, well-differentiated tumor xenografts from primary patient PNETs is challenging and is yet to be consistently achieved.

Studies in the RIP-Tag2 metastatic insulinoma mouse model of aggressive islet $\beta$-cell tumors found that antiVEGF therapy reduced tumor burden, but increased hypoxia and c-MET expression and activation, and also increased tumor cell invasion and metastasis (Sennino et al. 2012). Initial inhibition of VEGF using either antiVEGF antibodies or sunitinib showed decreased tumor size by 75 and 78\%, respectively. Simultaneously, c-MET mRNA level increased 3-fold in the anti-VEGF treatment group and 6-fold in the sunitinib treatment group compared to control samples. While these tumors were smaller in size, irregular tumor borders and increased expression of proliferative markers showed their invasiveness had increased. To confirm that this enhanced invasiveness was related to increased c-MET expression, mice were treated with a c-MET inhibitor PF-04217903 together with sunitinib, or XL184 (cabozantinib) which simultaneously blocks c-MET and VEGF. Significant reductions were noted in the invasion index in both anti-VEGF and sunitinib groups, showing tumor invasion was reduced by c-MET inhibition with simultaneous anti-VEGF treatment.

Additional studies also support the role of c-MET in tumorigenesis of MEN1-associated NETs. In the mouse MIN6 insulinoma cell line, menin was shown to target and upregulate MEG3, a long ncRNA that has tumorsuppressor properties in insulinoma (Miyazaki et al. 1990, Modali et al. 2015). Ectopic menin expression was observed to lead to an activating chromatin modification (H3K4me3) in the MEG3 promotor region. Subsequent MEG3 overexpression in MIN6 cells decreased proliferation and inhibited c-MET transcription (Modali et al. 2015) (Fig. 2). MIN6 cells with reduced c-MET expression had decreased migration and invasion. Furthermore, a reciprocal relationship between menin loss (i.e., MEG3 loss) and c-MET overexpression was detected in both human and mouse PNETs using immunohistochemical (IHC) staining, suggesting an oncogenic role of c-MET in MEN1-associated PNETs.

Also utilizing the MIN6 insulinoma line, the phosphorylated form of a $\beta$-cell specific transcription factor HLXB9 was shown to target the Cblb gene, which is an inhibitor of c-MET, thus controlling cell growth and proliferation (Desai et al. 2015). An increase in phosphoHLXB9 correlated with decreased Cblb expression and thus increased expression of c-MET, elucidating phosphoHLXB9's role as a pro-oncogenic agent with the potential to promote c-MET activation in an insulinoma cell line.

Using gene expression microarray assays, c-MET was found to be overexpressed by 4.9 -fold in human metastatic PNETs $(n=7)$ compared to nonmetastatic PNETs ( $n=5$ ) (Hansel et al. 2004). In support of the role of c-MET in the progression and tumor invasion to metastatic sites, IHC staining of tissue microarrays to verify c-MET overexpression showed 33\% of metastatic PNETs $(n=15)$ had higher c-MET compared to $17 \%$ of nonmetastatic lesions $(n=24)$. Increased c-MET expression was also observed in lymph node metastases $(4 / 7,57 \%)$ and in liver metastases $(5 / 9,56 \%)$. While c-MET expression was not found to be predictive of metastasis, the observation that expression was increased in metastases suggests that c-MET may play a role in the metastatic potential of PNETs (Hansel et al. 2004). Further support for this observation comes from a correlation between c-MET overexpression in 24 insulinomas and 3 hepatic metastases with the Ki-67 proliferative index (Murat et al. 2015).

MEN1, alpha thalassemia/mental retardation syndrome X-linked (ATRX) and death domain-associated protein $(D A X X)$ are among the most commonly mutated (c) 2020 Society for Endocrinology Published by Bioscientifica Ltd. Printed in Great Britain 

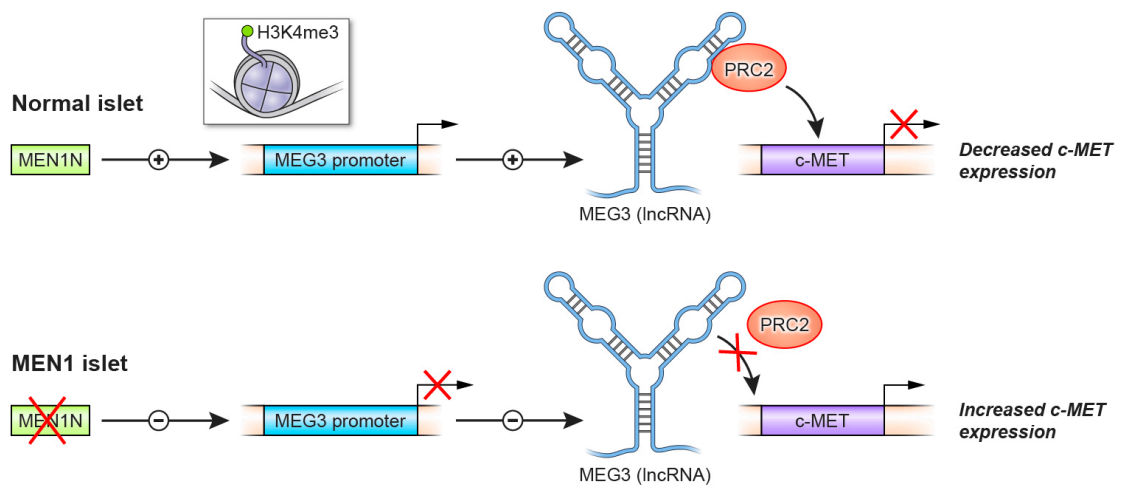

\section{Figure 2}

Effect of menin loss on MEG3 and c-MET expression. The top panel represents effects in an islet cell that has normal menin expression. Menin facilitates an activating histone trimethylation mark (H3K4me3) in the promoter region of the long non-coding RNA (IncRNA) $M E G 3$, leading to an increase in its expression. MEG3 interacts with the inhibitory multi-subunit polycomb repressive 2 protein complex (PRC2), to suppress the c-MET gene and thus decrease c-MET expression (the basal/normal level of c-MET). In islets with biallelic menin loss (lower panel), there is loss of the activating H3K4 trimethylation event at the MEG3 promoter, leading to decreased MEG3 expression, which increases c-MET expression due to loss of repressive chromatin marks in the c-MET gene associated with PRC2 recruitment. genes in sporadic PNETs, found in 40, 10, and 20\% of tumors, respectively (Jiao et al. 2011, Scarpa et al. 2017, Chan et al. 2018, Raj et al. 2018). In an analysis of whole exome sequencing of PNETs, 58\% of 64 PNETs were found to carry mutations in these genes (Chan et al. 2018). In the same study, RNAseq analysis showed PNETs that carried mutations in either MEN1, DAXX, or ATRX had 7.3-fold lower MEG3 expression and 3-fold higher c-MET expression compared to wild-type PNETs, which also coincided with worse recurrence free survival according to Kaplan-Meier analysis. Interestingly, PNETs carrying mutated versions of these genes (MEN1, DAXX, or ATRX) had a gene expression signature very close to that of pancreatic $\alpha$ cells, supporting the possibility that PNETs either originate from or differentiate into a cell type that is similar to $\alpha$ cells, which express increased c-MET (Chan et al. 2018).

These findings suggest a possible mechanism whereby aggressiveness and metastasis of PNETs may be dependent on c-MET expression. The observed inverse relationship between c-MET vs menin and MEG3 expression supports the co-existence of tumor-suppressing roles of menin and MEG3. With this in mind, c-MET inhibitors represent an attractive targeted therapy for the management of aggressive GEP NETs in MEN1 and similar sporadic tumors, warranting additional clinical trials and investigation.

\section{Conclusions and future directions}

GEP NETs are increasing in frequency and lack effective therapies once they become inoperable. In MEN1 patients, multifocal GEP NETs possess malignant capacity, with the added challenge of definitively identifying the culprit primary tumor. While medical therapies exist for some non-operable tumors, there remains a paucity of options that utilize molecularly identified targets. Mechanistic insights from recent studies show that menin loss may lead to subsequent upregulation of the HGF receptor c-MET, supporting c-MET inhibition as a therapeutic target. Similar overexpression of c-MET in sporadic PNETs shows a potential of c-MET inhibitors for the treatment of these tumors. Plausible biological mechanisms (e.g. menin loss correlating with the downregulation of MEG3, leading to increased expression of c-MET and increased migration/invasion), support an oncogenic role of c-MET in MEN1-associated tumorigenesis. Further clinical trials of c-MET inhibition in GEP NETs, specifically including patients with sporadic and MEN1 syndrome-related NETS, would help further advance our understanding and potentially provide a precision medicine approach.

\section{Declaration of interest}

The authors declare that there is no conflict of interest that could be perceived as prejudicing the impartiality of this review.

\section{Funding}

$M E L, A A T, A M, L S W, S K A$, and J E B are supported by funding from the Intramural Research Program of the National Institute of Diabetes and Digestive and Kidney Diseases (NIDDK). J D R is supported by the Intramural Research Program of the National Cancer Institute (NCI).

\section{References}

Agarwal SK 2017 The future: genetics advances in MEN1 therapeutic approaches and management strategies. Endocrine-Related Cancer 24 T119-T134. (https://doi.org/10.1530/ERC-17-0199)

Baljevic M, Zaman S, Baladandayuthapani V, Lin YH, De Partovi CM, Berkova Z, Amini B, Thomas SK, Shah JJ, Weber DM, et al. 2017 Phase II study of the c-MET inhibitor tivantinib (ARQ 197) in patients with relapsed or relapsed/refractory multiple myeloma. Annals of Hematology 96 977-985. (https://doi.org/10.1007/s00277017-2980-3) 
Beijers HJBH, Stikkelbroeck NML, Mensenkamp AR, Pfundt R, Van Der Luijt RB, Timmers HJLM, Hermus ARMM \& Kempers MJE 2019 Germline and somatic mosaicism in a family with multiple endocrine neoplasia type 1 (MEN1) syndrome. European Journal of Endocrinology 180 K15-K19. (https://doi.org/10.1530/EJE-18-0778)

Benten D, Behrang Y, Unrau L, Weissmann V, Wolters-Eisfeld G, BurdakRothkamm S, Stahl FR, Anlauf M, Grabowski P, Mobs M, et al. 2018 Establishment of the first well-differentiated human pancreatic neuroendocrine tumor model. Molecular Cancer Research 16 496-507. (https://doi.org/10.1158/1541-7786.MCR-17-0163)

Bertolino P, Tong WM, Galendo D, Wang ZQ \& Zhang CX 2003a Heterozygous Men1 mutant mice develop a range of endocrine tumors mimicking multiple endocrine neoplasia type 1. Molecular Endocrinology 17 1880-1892. (https://doi.org/10.1210/me.2003-0154)

Bertolino P, Tong WM, Herrera PL, Casse H, Zhang CX \& Wang ZQ $2003 b$ Pancreatic beta-cell-specific ablation of the multiple endocrine neoplasia type 1 (MEN1) gene causes full penetrance of insulinoma development in mice. Cancer Research 63 4836-4841.

Biondi CA, Gartside MG, Waring P, Loffler KA, Stark MS, Magnuson MA, Kay GF \& Hayward NK 2004 Conditional inactivation of the Men1 gene leads to pancreatic and pituitary tumorigenesis but does not affect normal development of these tissues. Molecular and Cellular Biology 24 3125-3131. (https://doi.org/10.1128/mcb.24.8.31253131.2004)

Bladt F, Friese-Hamim M, Ihling C, Wilm C \& Blaukat A 2014 The c-Met inhibitor MSC2156119J effectively inhibits tumor growth in liver cancer models. Cancers 6 1736-1752. (https://doi.org/10.3390/ cancers6031736)

Bradley CA, Salto-Tellez M, Laurent-Puig P, Bardelli A, Rolfo C, Tabernero J, Khawaja HA, Lawler M, Johnston PG, Van Schaeybroeck S, et al. 2017 Targeting c-MET in gastrointestinal tumours: rationale, opportunities and challenges. Nature Reviews: Clinical Oncology 14 562-576. (https://doi.org/10.1038/ nrclinonc.2017.40)

Byun J, Kim SH, Jeong HS, Rhee Y, Lee WJ \& Kang CM 2017 ACTHproducing neuroendocrine tumor of the pancreas: a case report and literature review. Annals of Hepato-Biliary-Pancreatic Surgery 21 61-65. (https://doi.org/10.14701/ahbps.2017.21.1.61)

Caplin ME, Pavel M \& Ruszniewski P 2014 Lanreotide in metastatic enteropancreatic neuroendocrine tumors. New England Journal of Medicine 371 1556-1557. (https://doi.org/10.1056/NEJMc1409757)

Catenacci DVT, Tebbutt NC, Davidenko I, Murad AM, Al-Batran SE, Ilson DH, Tjulandin S, Gotovkin E, Karaszewska B, Bondarenko I, et al. 2017 Rilotumumab plus epirubicin, cisplatin, and capecitabine as first-line therapy in advanced MET-positive gastric or gastrooesophageal junction cancer (RILOMET-1): a randomised, doubleblind, placebo-controlled, phase 3 trial. Lancet: Oncology 18 1467-1482. (https://doi.org/10.1016/S1470-2045(17)30566-1)

Challis BG, Casey RT, Grossman A, Newell-Price J, Newey P \& Thakker RV 2019 What is the appropriate management of nonfunctioning pancreatic neuroendocrine tumours disclosed on screening in adult patients with multiple endocrine neoplasia type 1? Clinical Endocrinology 91 708-715. (https://doi.org/10.1111/ cen.14094)

Chan JA, Faris JE, Murphy JE, Blaszkowsky LS, Kwak EL, Mccleary NJ, Fuchs CS, Meyerhardt JA, Ng K, Zhu AX, et al. 2017 Phase II trial of cabozantinib in patients with carcinoid and pancreatic neuroendocrine tumors (pNET). Journal of Clinical Oncology 35 228-228. (https://doi.org/10.1200/JCO.2017.35.4_suppl.228)

Chan CS, Laddha SV, Lewis PW, Koletsky MS, Robzyk K, Da Silva E, Torres PJ, Untch BR, Li J, Bose P, et al. 2018 ATRX, DAXX or MEN1 mutant pancreatic neuroendocrine tumors are a distinct alpha-cell signature subgroup. Nature Communications 9 4158. (https://doi. org/10.1038/s41467-018-06498-2)

Chandrasekharappa SC, Guru SC, Manickam P, Olufemi SE, Collins FS, Emmert-Buck MR, Debelenko LV, Zhuang Z, Lubensky IA, Liotta LA, et al. 1997 Positional cloning of the gene for multiple endocrine neoplasia-type 1. Science 276 404-407. (https://doi.org/10.1126/ science.276.5311.404)

Choe J, Kim KW, Kim HJ, Kim DW, Kim KP, Hong SM, Ryu JS, Tirumani SH, Krajewski K \& Ramaiya N 2019 What is new in the 2017 World Health Organization classification and 8th American Joint Committee on cancer staging system for pancreatic neuroendocrine neoplasms? Korean Journal of Radiology 20 5-17. (https://doi.org/10.3348/kjr.2018.0040)

Cives M \& Strosberg J 2015 The expanding role of somatostatin analogs in gastroenteropancreatic and lung neuroendocrine tumors. Drugs $\mathbf{7 5}$ 847-858. (https://doi.org/10.1007/s40265-015-0397-7)

Conemans EB, Brosens LAA, Raicu-Ionita GM, Pieterman CRC, De Herder WW, Dekkers OM, Hermus AR, Van Der Horst-Schrivers AN, Bisschop PH, Havekes B, et al. 2017 a Prognostic value of WHO grade in pancreatic neuro-endocrine tumors in Multiple Endocrine Neoplasia type 1: results from the DutchMEN1 Study Group. Pancreatology 17 766-772. (https://doi.org/10.1016/j. pan.2017.07.196)

Conemans EB, Nell S, Pieterman CRC, De Herder WW, Dekkers OM, Hermus AR, Van Der Horst-Schrivers AN, Bisschop PH, Havekes B, Drent ML, et al. 2017b Prognostic factors for survival of MEN1 patients WITH duodenopancreatic tumors metastatic to the liver: results FROM the DMSG. Endocrine Practice 23 641-648. (https://doi. org/10.4158/EP161639.OR)

Crabtree JS, Scacheri PC, Ward JM, Garrett-Beal L, Emmert-Buck MR, Edgemon KA, Lorang D, Libutti SK, Chandrasekharappa SC, Marx SJ, et al. 2001 A mouse model of multiple endocrine neoplasia, type 1 , develops multiple endocrine tumors. PNAS 98 1118-1123. (https:// doi.org/10.1073/pnas.98.3.1118)

Crabtree JS, Scacheri PC, Ward JM, Mcnally SR, Swain GP, Montagna C, Hager JH, Hanahan D, Edlund H, Magnuson MA, et al. 2003 Of mice and MEN1: insulinomas in a conditional mouse knockout. Molecular and Cellular Biology 23 6075-6085. (https://doi.org/10.1128/ mcb.23.17.6075-6085.2003)

Dasari A, Shen C, Halperin D, Zhao B, Zhou S, Xu Y, Shih T \& Yao JC 2017 Trends in the incidence, prevalence, and survival outcomes in patients with neuroendocrine tumors in the United States. JAMA Oncology 3 1335-1342. (https://doi.org/10.1001/ jamaoncol.2017.0589)

De Laat JM, Van Der Luijt RB, Pieterman CR, Oostveen MP, Hermus AR, Dekkers OM, De Herder WW, Van Der Horst-Schrivers AN, Drent ML, Bisschop PH, et al. 2016 MEN1 redefined, a clinical comparison of mutation-positive and mutation-negative patients. BMC Medicine 14 182. (https://doi.org/10.1186/s12916-016-0708-1)

Deeks ED \& Raymond E 2011 Sunitinib: in advanced, well differentiated pancreatic neuroendocrine tumors. BioDrugs 25 307-316. (https:// doi.org/10.2165/11207360-000000000-00000)

Demeure MJ, Klonoff DC, Karam JH, Duh QY \& Clark OH 1991 Insulinomas associated with multiple endocrine neoplasia type I: the need for a different surgical approach. Surgery 110 998-1004; discussion 1004-1005.

Desai SS, Kharade SS, Parekh VI, Iyer S \& Agarwal SK 2015 Pro-oncogenic roles of HLXB9 protein in insulinoma cells through interaction with nono protein and down-regulation of the c-Met inhibitor Cblb (casitas B-lineage lymphoma b). Journal of Biological Chemistry 290 25595-25608. (https://doi.org/10.1074/jbc.M115.661413)

Dralle H, Krohn SL, Karges W, Boehm BO, Brauckhoff M \& Gimm O 2004 Surgery of resectable nonfunctioning neuroendocrine pancreatic tumors. World Journal of Surgery 28 1248-1260. (https:// doi.org/10.1007/s00268-004-7609-8)

Dromain C, Pavel ME, Ruszniewski P, Langley A, Massien C, Baudin E, Caplin ME \& CLARINET Study Group 2019 Tumor growth rate as a metric of progression, response, and prognosis in pancreatic and intestinal neuroendocrine tumors. BMC Cancer 19 66. (https://doi. org/10.1186/s12885-018-5257-x) 
Eder JP, Shapiro GI, Appleman LJ, Zhu AX, Miles D, Keer H, Cancilla B, Chu F, Hitchcock-Bryan S, Sherman L, et al. 2010 A phase I study of foretinib, a multi-targeted inhibitor of c-Met and vascular endothelial growth factor receptor 2. Clinical Cancer Research 16 3507-3516. (https://doi.org/10.1158/1078-0432.CCR-10-0574)

Evers BM, Townsend CM, Upp JR, Allen E, Hurlbut SC, Kim SW, Rajaraman S, Singh P, Reubi JC \& Thompson JC 1991 Establishment and characterization of a human carcinoid in nude mice and effect of various agents on tumor growth. Gastroenterology 101 303-311. (https://doi.org/10.1016/0016-5085(91)90004-5)

Faivre S, Kroemer G \& Raymond E 2006 Current development of mTOR inhibitors as anticancer agents. Nature Reviews: Drug Discovery 5 671-688. (https://doi.org/10.1038/nrd2062)

Falchook GS, Kurzrock R, Amin HM, Xiong W, Fu S, Piha-Paul SA, Janku F, Eskandari G, Catenacci DVT, Klevesath MB, et al. 2019 Firstin-man phase I trial of the selective MET inhibitor Tepotinib in patients with advanced solid tumors. Clinical Cancer Research 26 1237-1246. (https://doi.org/10.1158/1078-0432.CCR-19-2860)

Fani M, Nicolas GP \& Wild D 2017 Somatostatin receptor antagonists for imaging and therapy. Journal of Nuclear Medicine 58 61S-66S. (https://doi.org/10.2967/jnumed.116.186783)

Farina DA, Krogh KM \& Boike JR 2019 Chronic diarrhea secondary to newly diagnosed vipoma. Case Reports in Gastroenterology 13 225-229. (https://doi.org/10.1159/000494554)

Flaherty KT, Puzanov I, Kim KB, Ribas A, Mcarthur GA, Sosman JA, O'dwyer PJ, Lee RJ, Grippo JF, Nolop K, et al. 2010 Inhibition of mutated, activated BRAF in metastatic melanoma. New England Journal of Medicine 363 809-819. (https://doi.org/10.1056/ NEJMoa1002011)

Francis JM, Kiezun A, Ramos AH, Serra S, Pedamallu CS, Qian ZR, Banck MS, Kanwar R, Kulkarni AA, Karpathakis A, et al. 2013 Somatic mutation of CDKN1B in small intestine neuroendocrine tumors. Nature Genetics 45 1483-1486. (https://doi.org/10.1038/ ng.2821)

Frost M, Lines KE \& Thakker RV 2018 Current and emerging therapies for PNETs in patients with or without MEN1. Nature Reviews: Endocrinology 14 216-227. (https://doi.org/10.1038/nrendo.2018.3)

Gordon MS, Sweeney CS, Mendelson DS, Eckhardt SG, Anderson A, Beaupre DM, Branstetter D, Burgess TL, Coxon A, Deng H, et al. 2010 Safety, pharmacokinetics, and pharmacodynamics of AMG 102, a fully human hepatocyte growth factor-neutralizing monoclonal antibody, in a first-in-human study of patients with advanced solid tumors. Clinical Cancer Research 16 699-710. (https://doi. org/10.1158/1078-0432.CCR-09-1365)

Goudet P, Murat A, Binquet C, Cardot-Bauters C, Costa A, Ruszniewski P, Niccoli P, Ménégaux F, Chabrier G, Borson-Chazot F, et al. 2010 Risk factors and causes of death in MEN1 disease. A GTE (Groupe d'Etude des Tumeurs Endocrines) cohort study among 758 patients. World Journal of Surgery 34 249-255. (https://doi.org/10.1007/s00268-0090290-1)

Hanahan D 1985 Heritable formation of pancreatic beta-cell tumours in transgenic mice expressing recombinant insulin/simian virus 40 oncogenes. Nature 315 115-122. (https://doi.org/10.1038/315115a0)

Hansel DE, Rahman A, House M, Ashfaq R, Berg K, Yeo CJ \& Maitra A 2004 Met proto-oncogene and insulin-like growth factor binding protein 3 overexpression correlates with metastatic ability in welldifferentiated pancreatic endocrine neoplasms. Clinical Cancer Research 10 6152-6158. (https://doi.org/10.1158/1078-0432.CCR-040285)

Harding B, Lemos MC, Reed AA, Walls GV, Jeyabalan J, Bowl MR, Tateossian H, Sullivan N, Hough T, Fraser WD, et al. 2009 Multiple endocrine neoplasia type 1 knockout mice develop parathyroid, pancreatic, pituitary and adrenal tumours with hypercalcaemia, hypophosphataemia and hypercorticosteronaemia. Endocrine-Related Cancer 16 1313-1327. (https://doi.org/10.1677/ERC-09-0082)
Hirshberg B, Libutti SK, Alexander HR, Bartlett DL, Cochran C, Livi A, Chang R, Shawker T, Skarulis MC \& Gorden P 2002 Blind distal pancreatectomy for occult insulinoma, an inadvisable procedure. Journal of the American College of Surgeons 194 761-764. (https://doi. org/10.1016/s1072-7515(02)01177-8)

Hopper AD, Jalal M \& Munir A 2019 Recent advances in the diagnosis and management of pancreatic neuroendocrine tumours. Frontline Gastroenterology 10 269-274. (https://doi.org/10.1136/ flgastro-2018-101006)

Janne PA, Shaw AT, Camidge DR, Giaccone G, Shreeve SM, Tang Y, Goldberg Z, Martini JF, Xu H, James LP, et al. 2016 Combined panHER and ALK/ROS1/MET inhibition with dacomitinib and crizotinib in advanced non-small cell lung cancer: results of a phase I study. Journal of Thoracic Oncology 11 737-747. (https://doi.org/10.1016/j. jtho.2016.01.022)

Jensen RT, Cadiot G, Brandi ML, De Herder WW, Kaltsas G, Komminoth P, Scoazec JY, Salazar R, Sauvanet A, Kianmanesh R, et al. 2012 ENETS Consensus Guidelines for the management of patients with digestive neuroendocrine neoplasms: functional pancreatic endocrine tumor syndromes. Neuroendocrinology 95 98-119. (https://doi.org/10.1159/000335591)

Jiao Y, Shi C, Edil BH, De Wilde RF, Klimstra DS, Maitra A, Schulick RD Tang LH, Wolfgang CL, Choti MA, et al. 2011 DAXX/ATRX, MEN1, and $\mathrm{mTOR}$ pathway genes are frequently altered in pancreatic neuroendocrine tumors. Science 331 1199-1203. (https://doi. org/10.1126/science.1200609)

Kaku M, Nishiyama T, Yagawa K \& Abe M 1980 Establishment of a carcinoembryonic antigen-producing cell line from human pancreatic carcinoma. Gan 71 596-601.

Kang YK, Muro K, Ryu MH, Yasui H, Nishina T, Ryoo BY, Kamiya Y, Akinaga S \& Boku N 2014 A phase II trial of a selective c-Met inhibitor tivantinib (ARQ 197) monotherapy as a second- or thirdline therapy in the patients with metastatic gastric cancer. Investigational New Drugs 32 355-361. (https://doi.org/10.1007/ s10637-013-0057-2)

Keedy VL, Lenz HJ, Saltz L, Whisenant JG, Berlin JD \& Camacho LH 2018 First-in-human phase I dose escalation study of MK-8033 in patients with advanced solid tumors. Investigational New Drugs 36 860-868. (https://doi.org/10.1007/s10637-018-0567-z)

Krampitz GW, George BM, Willingham SB, Volkmer JP, Weiskopf K, Jahchan N, Newman AM, Sahoo D, Zemek AJ, Yanovsky RL, et al. 2016 Identification of tumorigenic cells and therapeutic targets in pancreatic neuroendocrine tumors. PNAS 113 4464-4469. (https:// doi.org/10.1073/pnas.1600007113)

Kulke MH, Lenz HJ, Meropol NJ, Posey J, Ryan DP, Picus J, Bergsland E, Stuart K, Tye L, Huang X, et al. 2008 Activity of sunitinib in patients with advanced neuroendocrine tumors. Journal of Clinical Oncology 26 3403-3410. (https://doi.org/10.1200/JCO.2007.15.9020)

Kyriakopoulos CE, Braden AM, Kolesar JM, Eickhoff JC, Bailey HH, Heideman J, Liu G \& Wisinski KB 2017 A phase I study of tivantinib in combination with temsirolimus in patients with advanced solid tumors. Investigational New Drugs 35 290-297. (https://doi. org/10.1007/s10637-016-0418-8)

Lee J, Kim ST, Park S, Lee S, Park SH, Park JO, Lim HY, Ahn H, Bok H, Kim KM, et al. 2018 Phase I trial of anti-MET monoclonal antibody in MET-overexpressed refractory cancer. Clinical Colorectal Cancer 17 140-146. (https://doi.org/10.1016/j.clcc.2018.01.005)

Lemmens I, Van De Ven WJ, Kas K, Zhang CX, Giraud S, Wautot V, Buisson N, De Witte K, Salandre J, Lenoir G, et al. 1997 Identification of the multiple endocrine neoplasia type 1 (MEN1) gene. The European Consortium on MEN1. Human Molecular Genetics 6 1177-1183. (https://doi.org/10.1093/hmg/6.7.1177)

Lewis A, Li D, Williams J \& Singh G 2017 Pancreatic neuroendocrine tumors: state-of-the-art diagnosis and management. Oncology $\mathbf{3 1}$ e1-e12. 
Loffler KA, Biondi CA, Gartside MG, Serewko-Auret MM, Duncan R, Tonks ID, Mould AW, Waring P, Muller HK, Kay GF, et al. 2007 Lack of augmentation of tumor spectrum or severity in dual heterozygous Men1 and Rb1 knockout mice. Oncogene 26 4009-4017. (https://doi. org/10.1038/sj.onc.1210163)

Luo Y, Pan Q, Yao S, Yu M, Wu W, Xue H, Kiesewetter DO, Zhu Z, Li F, Zhao Y, et al. 2016 Glucagon-like peptide-1 receptor PET/CT with 68Ga-NOTA-Exendin-4 for detecting localized insulinoma: a prospective cohort study. Journal of Nuclear Medicine 57 715-720. (https://doi.org/10.2967/jnumed.115.167445)

Lynch TJ, Bell DW, Sordella R, Gurubhagavatula S, Okimoto RA, Brannigan BW, Harris PL, Haserlat SM, Supko JG, Haluska FG, et al. 2004 Activating mutations in the epidermal growth factor receptor underlying responsiveness of non-small-cell lung cancer to gefitinib. New England Journal of Medicine 350 2129-2139. (https://doi. org/10.1056/NEJMoa040938)

Maron SB, Karrison T, Kanteti R, Rao KA, Gandara DR, Koczywas M, Salgia R \& Kindler HL 2015 ARQ 197 in patients with previouslytreated malignant mesothelioma (MM): a phase II trial from the University of Chicago Phase II Consortium. Journal of Clinical Oncology 33 7511-7511. (https://doi.org/10.1200/jco.2015.33.15_suppl.7511)

Michaelson MD, Gupta S, Agarwal N, Szmulewitz R, Powles T, Pili R, Bruce JY, Vaishampayan U, Larkin J, Rosbrook B, et al. 2019 A phase Ib study of axitinib in combination with crizotinib in patients with metastatic renal cell cancer or other advanced solid tumors. Oncologist 24 1151-e817. (https://doi.org/10.1634/ theoncologist.2018-0749)

Miyazaki J, Araki K, Yamato E, Ikegami H, Asano T, Shibasaki Y, Oka Y \& Yamamura K 1990 Establishment of a pancreatic beta cell line that retains glucose-inducible insulin secretion: special reference to expression of glucose transporter isoforms. Endocrinology 127 126-132. (https://doi.org/10.1210/endo-127-1-126)

Modali SD, Parekh VI, Kebebew E \& Agarwal SK 2015 Epigenetic regulation of the IncRNA MEG3 and its target c-MET in pancreatic neuroendocrine tumors. Molecular Endocrinology 29 224-237. (https:// doi.org/10.1210/me.2014-1304)

Modlin IM, Drozdov I \& Kidd M 2013 The identification of gut neuroendocrine tumor disease by multiple synchronous transcript analysis in blood. PLoS ONE 8 e63364. (https://doi.org/10.1371/ journal.pone.0063364)

Molife LR, Dean EJ, Blanco-Codesido M, Krebs MG, Brunetto AT, Greystoke AP, Daniele G, Lee L, Kuznetsov G, Myint KT, et al. 2014 A phase I, dose-escalation study of the multitargeted receptor tyrosine kinase inhibitor, golvatinib, in patients with advanced solid tumors. Clinical Cancer Research 20 6284-6294. (https://doi. org/10.1158/1078-0432.CCR-14-0409)

Monk P, Liu G, Stadler WM, Geyer S, Huang Y, Wright J, VillalonaCalero M, Wade J, Szmulewitz R, Gupta S, et al. 2018 Phase II randomized, double-blind, placebo-controlled study of tivantinib in men with asymptomatic or minimally symptomatic metastatic castration-resistant prostate cancer (mCRPC). Investigational New Drugs 36 919-926. (https://doi.org/10.1007/s10637-018-0630-9)

Mughal A, Aslam HM, Sheikh A, Khan AM \& Saleem S 2013 c-Met inhibitors. Infectious Agents and Cancer 8 13. (https://doi. org/10.1186/1750-9378-8-13)

Murat C d B, Da Rosa B, Fortes PW, Correa MA, Machado L, Novak MC, Siqueira EM, Pereira SA, Correa-Giannella MA, Giannella-Neto MLD, et al. 2015. Differential expression of genes encoding proteins of the HGF/MET system in insulinomas. Diabetology and Metabolic Syndrome 7 84. (https://doi.org/10.1186/ s13098-015-0079-3)

Okabayashi T, Shima Y, Sumiyoshi T, Kozuki A, Ito S, Ogawa Y, Kobayashi M \& Hanazaki K 2013 Diagnosis and management of insulinoma. World Journal of Gastroenterology 19 829-837. (https:// doi.org/10.3748/wjg.v19.i6.829)
Okusaka T, Aramaki T, Inaba Y, Nakamura S, Morimoto M, Moriguchi M, Sato T, Ikawa Y, Ikeda M \& Furuse J 2015 Phase I study of tivantinib in Japanese patients with advanced hepatocellular carcinoma: distinctive pharmacokinetic profiles from other solid tumors. Cancer Science 106 611-617. (https://doi.org/10.1111/cas.12644)

Pant S, Saleh M, Bendell J, Infante JR, Jones S, Kurkjian CD, Moore KM, Kazakin J, Abbadessa G, Wang Y, et al. 2014 A phase I dose escalation study of oral c-MET inhibitor tivantinib (ARQ 197) in combination with gemcitabine in patients with solid tumors. Annals of Oncology 25 1416-1421. (https://doi.org/10.1093/annonc/mdu157)

Pant S, Patel M, Kurkjian C, Hemphill B, Flores M, Thompson D \& Bendell J 2017 A phase II study of the c-Met inhibitor tivantinib in combination with FOLFOX for the treatment of patients with previously untreated metastatic adenocarcinoma of the distal esophagus, gastroesophageal junction, or stomach. Cancer Investigation 35 463-472. (https://doi.org/10.1080/07357907.2017.13 37782)

Parekh VI, Modali SD, Welch J, Simonds WF, Weinstein LS, Kebebew E \& Agarwal SK 2018 Frequency and consequence of the recurrent YY1 p.T372R mutation in sporadic insulinomas. Endocrine-Related Cancer 25 L31-L35. (https://doi.org/10.1530/ERC-17-0311)

Pavel ME, Hainsworth JD, Baudin E, Peeters M, Horsch D, Winkler RE, Klimovsky J, Lebwohl D, Jehl V, Wolin EM, et al. 2011 Everolimus plus octreotide long-acting repeatable for the treatment of advanced neuroendocrine tumours associated with carcinoid syndrome (RADIANT-2): a randomised, placebo-controlled, phase 3 study. Lancet 378 2005-2012. (https://doi.org/10.1016/S01406736(11)61742-X)

Peters S \& Adjei AA 2012 MET: a promising anticancer therapeutic target. Nature Reviews: Clinical Oncology 9 314-326. (https://doi. org/10.1038/nrclinonc.2012.71)

Porta C, Giglione P, Ferrari A, Reversi F, Liguigli W, Imarisio I \& Ganini C 2015 Tivantinib (ARQ197) in hepatocellular carcinoma. Expert Review of Anticancer Therapy 15 615-622. (https://doi.org/10.15 86/14737140.2015.1050383)

Puccini A, Marín-Ramos NI, Bergamo F, Schirripa M, Lonardi S, Lenz HJ, Loupakis F \& Battaglin F 2019 Safety and tolerability of c-MET inhibitors in cancer. Drug Safety 42 211-233. (https://doi. org/10.1007/s40264-018-0780-x)

Raj N, Shah R, Stadler Z, Mukherjee S, Chou J, Untch B, Li J, Kelly V, Saltz LB, Mandelker D, et al. 2018 Real-time genomic characterization of metastatic pancreatic neuroendocrine tumors has prognostic implications and identifies potential germline actionability. JCO Precision Oncology 2018 [epub]. (https://doi. org/10.1200/PO.17.00267)

Ramage JK, Davies AH, Ardill J, Bax N, Caplin M, Grossman A, Hawkins R, Mcnicol AM, Reed N, Sutton R, et al. 2005 Guidelines for the management of gastroenteropancreatic neuroendocrine (including carcinoid) tumours. Gut 54 (Supplement 4) iv1-i16. (https://doi.org/10.1136/gut.2004.053314)

Reubi JC 2004 Somatostatin and other peptide receptors as tools for tumor diagnosis and treatment. Neuroendocrinology 80 (Supplement 1) 51-56. (https://doi.org/10.1159/000080742)

Reubi JC, Schar JC, Waser B, Wenger S, Heppeler A, Schmitt JS \& Macke HR 2000 Affinity profiles for human somatostatin receptor subtypes SST1-SST5 of somatostatin radiotracers selected for scintigraphic and radiotherapeutic use. European Journal of Nuclear Medicine 27 273-282. (https://doi.org/10.1007/s002590050034)

Rindi G, Klimstra DS, Abedi-Ardekani B, Asa SL, Bosman FT, Brambilla E, Busam KJ, De Krijger RR, Dietel M, El-Naggar AK, et al. 2018 A common classification framework for neuroendocrine neoplasms: an International Agency for Research on Cancer (IARC) and World Health Organization (WHO) expert consensus proposal. Modern Pathology 31 1770-1786. (https://doi.org/10.1038/s41379-0180110-y) 
Rinke A, Neary MP, Eriksson J, Hunger M, Doan T, Karli D \& Arnold R 2019 Health-related quality of life for long-acting octreotide versus placebo in patients with metastatic midgut neuroendocrine tumors in the phase 3 PROMID trial. Neuroendocrinology 109 141-151. (https://doi.org/10.1159/000499469)

Rosen LS, Senzer N, Mekhail T, Ganapathi R, Chai F, Savage RE, Waghorne C, Abbadessa G, Schwartz B \& Dreicer R 2011 A phase I dose-escalation study of tivantinib (ARQ 197) in adult patients with metastatic solid tumors. Clinical Cancer Research 17 7754-7764. (https://doi.org/10.1158/1078-0432.CCR-11-1002)

Scarpa A, Chang DK, Nones K, Corbo V, Patch AM, Bailey P, Lawlor RT, Johns AL, Miller DK, Mafficini A, et al. 2017 Whole-genome landscape of pancreatic neuroendocrine tumours. Nature 543 65-71. (https://doi.org/10.1038/nature21063)

Schmidt L, Duh FM, Chen F, Kishida T, Glenn G, Choyke P, Scherer SW, Zhuang Z, Lubensky I, Dean M, et al. 1997 Germline and somatic mutations in the tyrosine kinase domain of the MET proto-oncogene in papillary renal carcinomas. Nature Genetics 16 68-73. (https://doi. org/10.1038/ng0597-68)

Sennino B, Ishiguro-Oonuma T, Wei Y, Naylor RM, Williamson CW, Bhagwandin V, Tabruyn SP, You WK, Chapman HA, Christensen JG, et al. 2012 Suppression of tumor invasion and metastasis by concurrent inhibition of c-Met and VEGF signaling in pancreatic neuroendocrine tumors. Cancer Discovery 2 270-287. (https://doi org/10.1158/2159-8290.CD-11-0240)

Shah MA, Wainberg ZA, Catenacci DV, Hochster HS, Ford J, Kunz P, Lee FC, Kallender H, Cecchi F, Rabe DC, et al. 2013 Phase II study evaluating 2 dosing schedules of oral foretinib (GSK1363089), cMET/ VEGFR2 inhibitor, in patients with metastatic gastric cancer. PLoS ONE 8 e54014. (https://doi.org/10.1371/journal.pone.0054014)

Shah MA, Cho JY, Tan IB, Tebbutt NC, Yen CJ, Kang A, Shames DS, Bu L \& Kang YK 2016 A randomized Phase II study of FOLFOX with or without the MET inhibitor onartuzumab in advanced adenocarcinoma of the stomach and gastroesophageal junction. Oncologist 21 1085-1090. (https://doi.org/10.1634/ theoncologist.2016-0038)

Simbolo M, Mafficini A, Sikora KO, Fassan M, Barbi S, Corbo V, Mastracci L, Rusev B, Grillo F, Vicentini C, et al. 2017 Lung neuroendocrine tumours: deep sequencing of the four World Health Organization histotypes reveals chromatin-remodelling genes as major players and a prognostic role for tert, RB1, MEN1 and KMT2D. Journal of Pathology 241 488-500. (https://doi.org/10.1002/path.4853)

Simbolo M, Barbi S, Fassan M, Mafficini A, Ali G, Vicentini C, Sperandio N, Corbo V, Rusev B, Mastracci L, et al. 2019 Gene expression profiling of lung atypical carcinoids and large cell neuroendocrine carcinomas identifies three transcriptomic subtypes with specific genomic alterations. Journal of Thoracic Oncology 14 1651-1661. (https://doi.org/10.1016/j.jtho.2019.05.003)

Strosberg J, El-Haddad G, Wolin E, Hendifar A, Yao J, Chasen B, Mittra E, Kunz PL, Kulke MH, Jacene H, et al. 2017 Phase 3 trial of (177)Lu-Dotatate for midgut neuroendocrine tumors. New England Journal of Medicine 376 125-135. (https://doi.org/10.1056/ NEJMoa1607427)

Tabernero J, Elez ME, Herranz M, Rico I, Prudkin L, Andreu J, Mateos J, Carreras MJ, Han M, Gifford J, et al. 2014 A pharmacodynamic/ pharmacokinetic study of ficlatuzumab in patients with advanced solid tumors and liver metastases. Clinical Cancer Research 20 2793-2804. (https://doi.org/10.1158/1078-0432.CCR-13-1837)

Tepede A, Welch J, Mandl A, Agarwal S, Nilubol N, Cochran C, Merkel R, Simonds W, Weinstein L, Jha A, et al. 2019 SAT-310 (18) F-FDOPA PET/CT accurately identifies pheochromocytoma in 70-year-old male with MEN1. Journal of the Endocrine Society 3 SAT310. (https://doi.org/10.1210/js.2019-SAT-310)

Thakker RV, Newey PJ, Walls GV, Bilezikian J, Dralle H, Ebeling PR, Melmed S, Sakurai A, Tonelli F, Brandi ML, et al. 2012 Clinical practice guidelines for multiple endocrine neoplasia Type 1 (MEN1).
Journal of Clinical Endocrinology and Metabolism 97 2990-3011. (https://doi.org/10.1210/jc.2012-1230)

Tirosh A, Journy N, Folio LR, Lee C, Leite C, Yao J, Kovacs W, Linehan WM, Malayeri A, Kebebew E, et al. 2019 Cumulative radiation exposures from CT screening and surveillance strategies for von Hippel-Lindau-associated solid pancreatic tumors. Radiology 290 116-124. (https://doi.org/10.1148/radiol.2018180687)

Toiyama Y, Yasuda H, Saigusa S, Matushita K, Fujikawa H, Tanaka K, Mohri Y, Inoue Y, Goel A \& Kusunoki M 2012 Co-expression of hepatocyte growth factor and c-Met predicts peritoneal dissemination established by autocrine hepatocyte growth factor/cMet signaling in gastric cancer. International Journal of Cancer 130 2912-2921. (https://doi.org/10.1002/ijc.26330)

Tolaney SM, Tan S, Guo H, Barry W, Van Allen E, Wagle N, Brock J, Larrabee K, Paweletz C, Ivanova E, et al. 2015 Phase II study of tivantinib (ARQ 197) in patients with metastatic triple-negative breast cancer. Investigational New Drugs 33 1108-1114. (https://doi. org/10.1007/s10637-015-0269-8)

Triponez F, Dosseh D, Goudet P, Cougard P, Bauters C, Murat A, Cadiot G, Niccoli-Sire P, Chayvialle JA, Calender A, et al. 2006 Epidemiology data on 108 MEN 1 patients from the GTE with isolated nonfunctioning tumors of the pancreas. Annals of Surgery 243 265-272. (https://doi.org/10.1097/01.sla.0000197715.96762.68)

Van Treijen MJC, Van Beek DJ, Van Leeuwaarde RS, Vriens MR \& Valk GD 2018 Diagnosing nonfunctional pancreatic NETs in MEN1: the evidence base. Journal of the Endocrine Society 2 1067-1088. (https://doi.org/10.1210/js.2018-00087)

Vandamme T, Peeters M, Dogan F, Pauwels P, Van Assche E, Beyens M, Mortier G, Vandeweyer G, De Herder W, Van Camp G, et al. 2015 Whole-exome characterization of pancreatic neuroendocrine tumor cell lines BON-1 and QGP-1. Journal of Molecular Endocrinology 54 137-147. (https://doi.org/10.1530/JME-14-0304)

Vargatu I 2016 Williams textbook of endocrinology. Acta Endocrinologica 12 113-113. (https://doi.org/10.4183/aeb.2016.113)

Vinault S, Mariet A-S, Le Bras M, Mirallié E, Cardot-Bauters C, Pattou F, Ruszniewski P, Sauvanet A, Chanson P, Baudin E, et al. 2018 Metastatic potential and survival of duodenal and pancreatic tumors in multiple endocrine neoplasia Type 1: a GTE and AFCE cohort study (Groupe d'étude des Tumeurs Endocrines and Association Francophone de Chirurgie Endocrinienne). Annals of Surgery [epub]. (https://doi.org/10.1097/SLA.0000000000003162)

Waldmann J, Habbe N, Fendrich V, Slater EP, Kann PH, Rothmund M \& Langer P 2008 Fast-growing pancreatic neuroendocrine carcinoma in a patient with multiple endocrine neoplasia type 1: a case report. Journal of Medical Case Reports 2 354. (https://doi.org/10.1186/17521947-2-354)

Wiedmann MW \& Mossner J 2012 Safety and efficacy of sunitinib in patients with unresectable pancreatic neuroendocrine tumors. Clinical Medicine Insights: Oncology 6 381-393. (https://doi. org/10.4137/CMO.S7350)

Wild D, Fani M, Fischer R, Del Pozzo L, Kaul F, Krebs S, Fischer R, Rivier JE, Reubi JC, Maecke HR, et al. 2014 Comparison of somatostatin receptor agonist and antagonist for peptide receptor radionuclide therapy: a pilot study. Journal of Nuclear Medicine $\mathbf{5 5}$ 1248-1252. (https://doi.org/10.2967/jnumed.114.138834)

Yamamoto N, Murakami H, Nishina T, Hirashima T, Sugio K, Muro K, Takahashi T, Naito T, Yasui H, Akinaga S, et al. 2013 The effect of CYP2C19 polymorphism on the safety, tolerability, and pharmacokinetics of tivantinib (ARQ 197): results from a phase I trial in advanced solid tumors. Annals of Oncology 24 1653-1659. (https://doi.org/10.1093/annonc/mdt014)

Yang MA, Lee WK, Shin HS, Park SH, Kim BS, Kim JW, Cho JW \& Yun SH 2017 Neuroendocrine tumors in the stomach, duodenum, and pancreas accompanied by novel MEN1 gene mutation. Korean Journal of Gastroenterology 69 181-186. (https://doi.org/10.4166/ kjg.2017.69.3.181) 
Yao JC, Phan AT, Chang DZ, Wolff RA, Hess K, Gupta S, Jacobs C, Mares JE, Landgraf AN, Rashid A, et al. 2008 Efficacy of RAD001 (everolimus) and octreotide LAR in advanced low- to intermediategrade neuroendocrine tumors: results of a phase II study. Journal of Clinical Oncology 26 4311-4318. (https://doi.org/10.1200/ JCO.2008.16.7858)

Yao JC, Shah MH, Ito T, Bohas CL, Wolin EM, Van Cutsem E, Hobday TJ, Okusaka T, Capdevila J, De Vries EGE, et al. 2011 Everolimus for advanced pancreatic neuroendocrine tumors. New England Journal of Medicine 364 514-523. (https://doi.org/10.1056/ NEJMoa1009290)

Yao JC, Fazio N, Singh S, Buzzoni R, Carnaghi C, Wolin E, Tomasek J, Raderer M, Lahner H, Voi M, et al. 2016 Everolimus for the treatment of advanced, non-functional neuroendocrine tumours of the lung or gastrointestinal tract (RADIANT-4): a randomised, placebo-controlled, phase 3 study. Lancet 387 968-977. (https://doi org/10.1016/S0140-6736(15)00817-X)

Zhang WD, Liu DR, Wang P, Zhao JG, Wang ZF \& Chen LI 2016 Clinical treatment of gastrinoma: a case report and review of the literature. Oncology Letters 11 3433-3437. (https://doi.org/10.3892/ ol.2016.4397)

Zhen DB, Griffith KA, Ruch JM, Camphausen K, Savage JE, Kim EJ, Sahai V, Simeone DM \& Zalupski MM 2016 A phase I trial of cabozantinib and gemcitabine in advanced pancreatic cancer. Investigational New Drugs 34 733-739. (https://doi.org/10.1007/ s10637-016-0376-1)

Zhuang Z, Vortmeyer AO, Pack S, Huang S, Pham TA, Wang C, Park WS, Agarwal SK, Debelenko LV, Kester M, et al. 1997 Somatic mutations of the MEN1 tumor suppressor gene in sporadic gastrinomas and insulinomas. Cancer Research 57 4682-4686.

Received in final form 28 April 2020

Accepted 7 May 2020

Accepted Manuscript published online 8 May 2020
(C) 2020 Society for Endocrinology Published by Bioscientifica Ltd. Printed in Great Britain 